Historic, archived document

Do not assume content reflects current scientific knowledge, policies, or practices. 
A.99.9

1.765

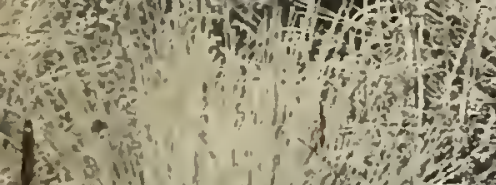

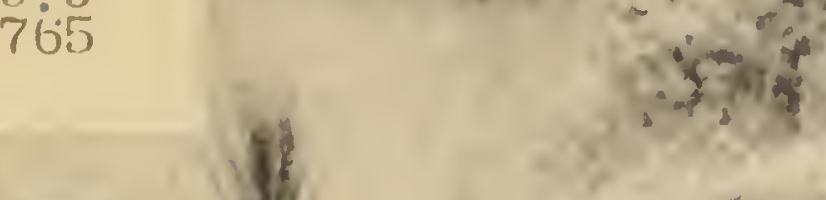

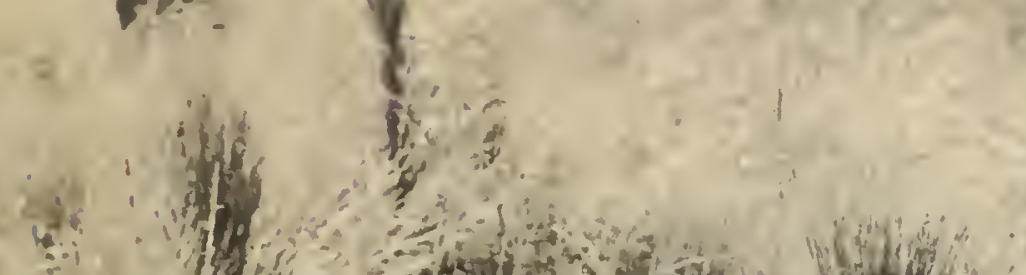

M

in

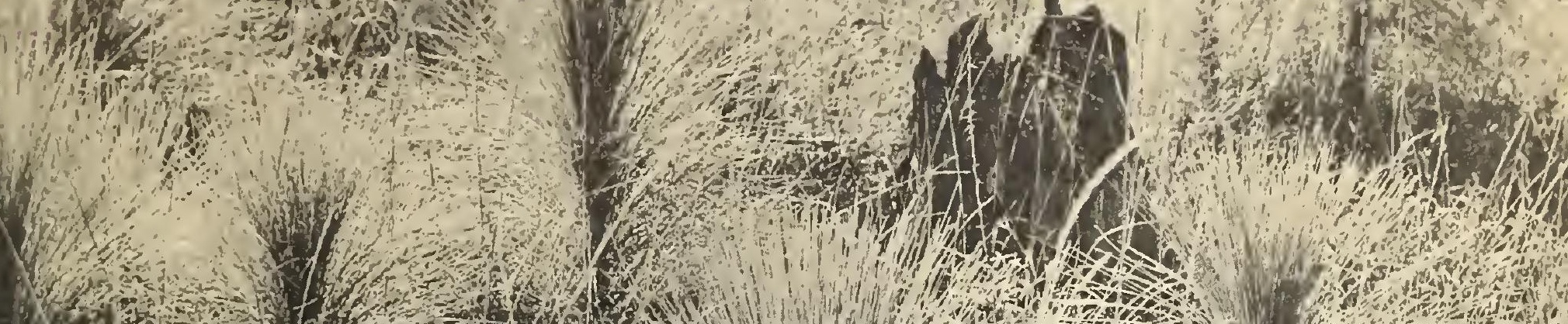

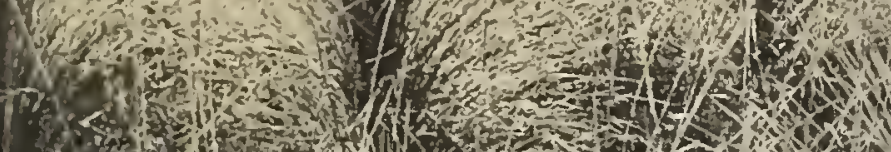

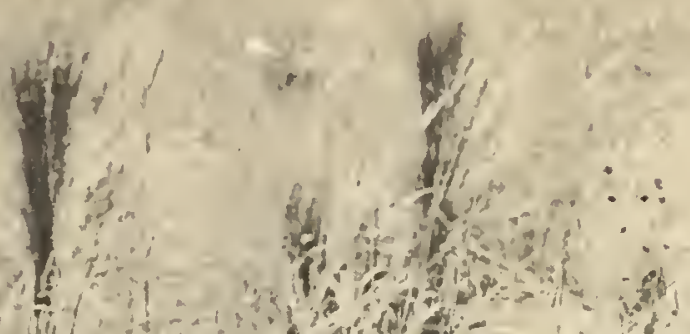

(4)

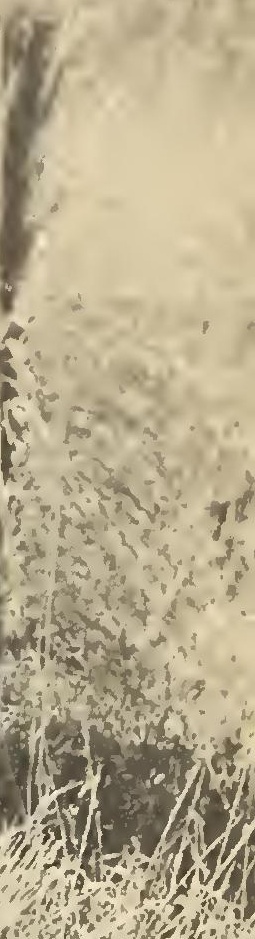

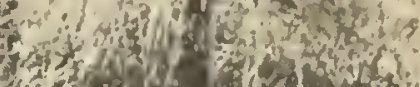

ind

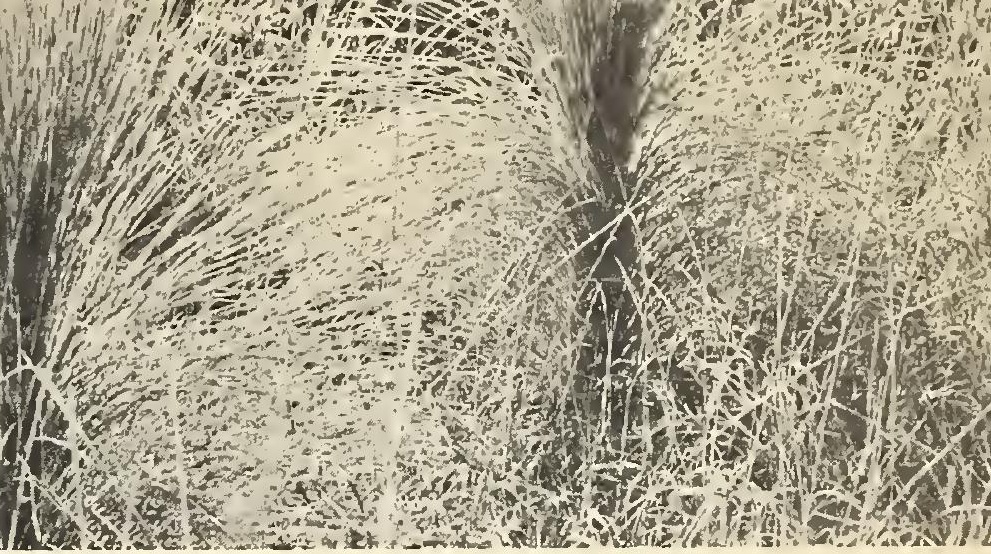

The Alexandria Research Center John T. Cassady and William F. Mann, Jr.

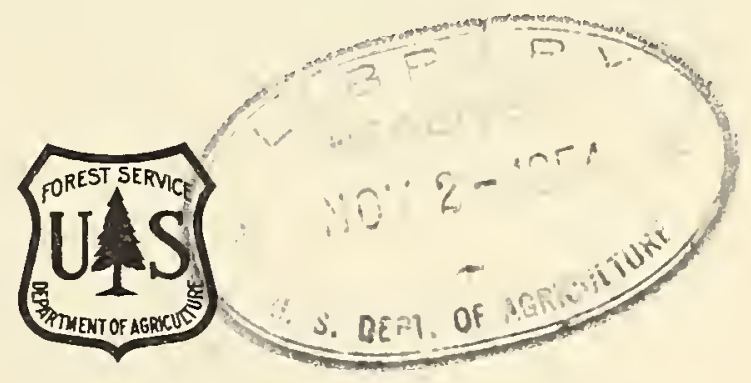

Southern Forest Experiment Station

Philip A. Briegleb, Director

Forest Service, U.S.Dep't of Agriculture 
Cover: Direct-seeded longleaf pines just starting height growth. (Photo by Elemore Morgan)

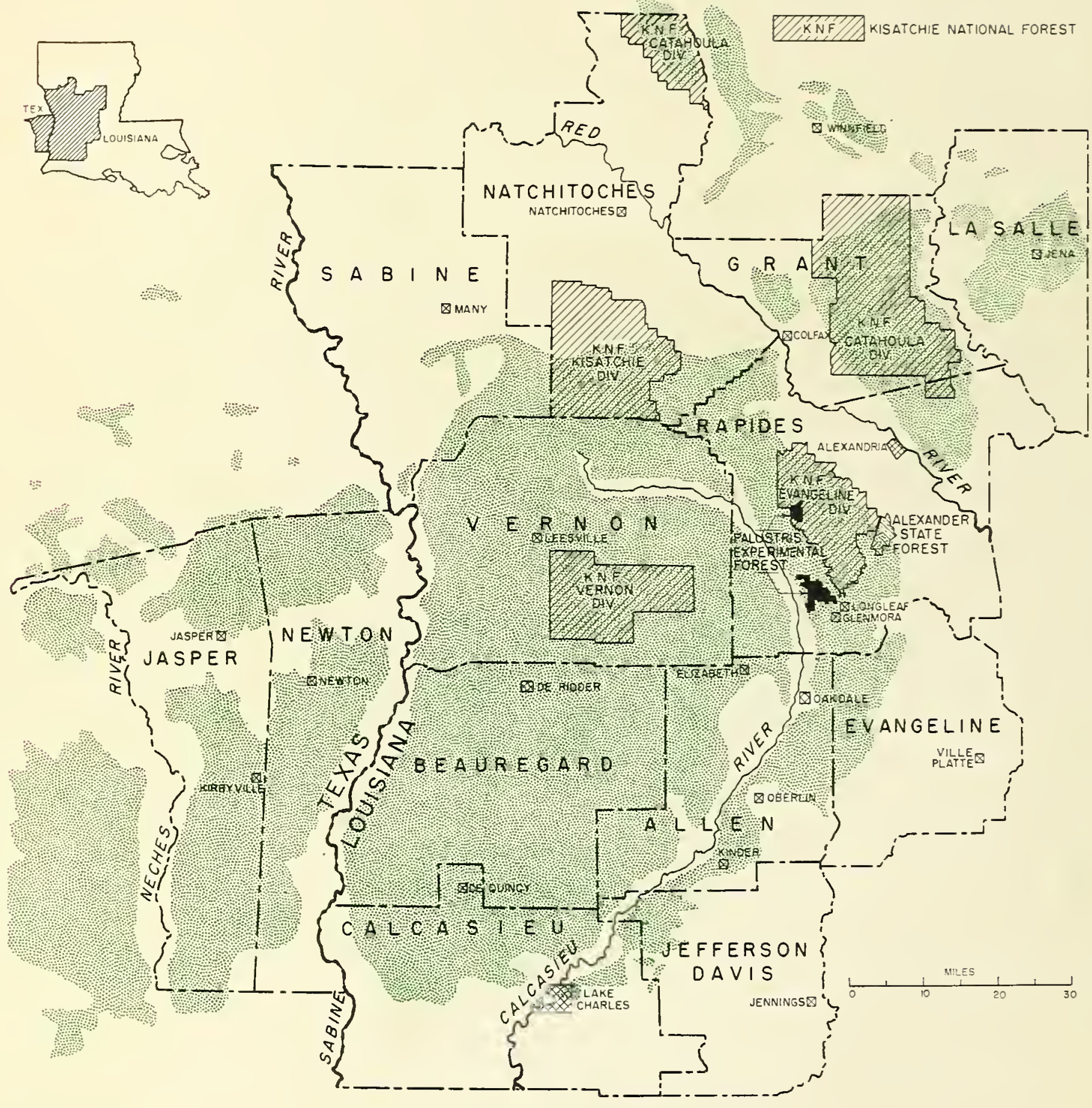

Figure 1.-- Territory served directly by the Alexandria Research Center. The green shading represents the area originally in longleaf pine forest. 
FOREWORD

This booklet describes the work of the Alexandria Research Center. The Center is a field unit of the Southern Forest Experiment Station, Forest Service, U. S. Department of Agriculture. Its special mission is to find practical solutions to the most urgent land-management problems of the cutover longleaf pine lands west of the Mississippi River (fig. 1).

The Research Center was established in July 1946. It did not have to start from scratch, however, for it was able to draw on work begun in 1934 by Forest Service technicians stationed in New Orleans. In this early period, Philip C. Wakeley, working at the Stuart Nursery and on the Palustris Experimental Forest, carried out much basic research in pine seed processing, nursery practices, and planting. Many of Wakeley's plantations are now being used for studies of thinning methods and other management techniques. In 1944 and 1945, Dr. R. S. Campbell started studies in forest grazing, forest range improvement, and the use of chemicals to control scrub oaks. By 1946, therefore, the Research Center had a very solid foundation on which to base its program.

The Center's chief field laboratory is the Palustris Experimental Forest, which consists of 7,830 acres in two separate tracts (figs. 26 and 27, pp. 48-49). The oldest is the J. K. Johnson Tract, which was established in 1935; it contains 2,030 acres. The second is the Longleaf Tract, an area of 5, 800 acres dedicated to research in 1950.

For several years after 1946, the Alexandria Research Center was financed almost entirely by Federal funds. More recently, public agencies, private industries, and individuals have contributed facilities, manpower, and money for cooperative studies. Among the cooperators are:

Louisiana Forestry Commission

Louisiana Forestry Association

Louisiana Agricultural Experiment Station

Kisatchie National Forest

Soil Conservation Service, U. S. Dept. of Agriculture

Fish and Wildlife Service, U. S. Dept. of the Interior 
Agricultural Research Service, U. S. Dept. of Agriculture A. J. Hodges Industries, Inc.

Nebo Oil Co.

Industrial Lumber Co.

International Paper Co.

Crosby Chemicals, Inc.

Roy O. Martin Lumber Co.

Hillyer-Deutsch-Edwards Lumber Co.

And eight individual cattle owners.

In early 1947, a research advisory committee was organized to help keep the research program aimed at the most vital technical problems. Currently the committee is made up of the following members:

R. W. Hayes

C. V. Holbrook

P. E. King

C. H. Lewis, Jr.

A. S. McKean

J. M. McLemore

J. E. Mixon

W. M. Palme $r, J r$.

B. A. Ryan

H. S. Redding

R. E. Williams
Director, School of Forestry, L. S. U. General Manager, Long-Bell Lumber Co. Chief Forester, Industrial Lumber Co. Chief Forester, Crosby Chemicals, Inc. Extension Forester, Agricultural Extension Service

Private landowner and cattleman

State Forester, Louisiana Forestry

Commission

Chief Forester, Nebo: Oil Co.

Division Forester, International Paper Co. Supervisor, Kisatchie National Forest Area Conservationist, Soil Conservation Service

The staff of the Alexandria Research Center is grateful to all who have cooperated to develop and maintain the work. Additional cooperation is in prospect, and it is anticipated that research can soon be started on problems that so far have had to be neglected because of insufficient facilities.

JOHN T. CASSADY

Officer in charge, Alexandria Research Center 
THE ALEXANDRIA RESEARCH CENTER

REFORESTING THE CUTOVER PINE LANDS . . . . . . . . 4

Choice of species. . . . . . . . . . . . . . . 4

Stimulating longleaf height growth . . . . . . . . 6

Direct seeding . . . . . . . . . . . . . . .

Stimulating seed production . . . . . . . . . . . 12

Converting scrub oak stands to pine. . . . . . . . 13

Forest tree improvement . . . . . . . . . . . . 14

MANAGING PINE PLANTATIONS FOR OPTIMUM RETURNS • • . 15

Thinning loblolly pine plantations . . . . . . . . 15

Management of longleaf plantations . . . . . . . . 17

Thinning slash pine plantations . . . . . . . . . . 19

CONTROLLING LOW-VALUE HARDWOODS WITH CHEMICALS . . 20

Effective methods developed . . . . . . . . . 21

IMPROVING MANAGEMENT OF LIVESTOCK AND FORAGE ON

FOREST RANGES . . . . . . . . . . . . • . . . 24

Management of livestock on forest range . . . . . . 25

Management of forage on forest range . . . . . . . 30

Improvement of forage on forest range. . . . . . . . 34

COST AND RETURNS OF GOOD FOREST MANAGEMENT . . . . 39

PUBLICATIONS . . . . . . . . . . . . . . . . . 41

$\underline{\text { MAPS }}$

Figure 1.--Territory served directly by the Alexandria

Research Center. . . . . . . . Inside front cover

Figure 26. --J. K. Johnson Tract . . . . . . . . . . 48

Figure 27. -- Longleaf Tract . . . . . . . . . . . . 49

Figure 28. - Main roads to Johnson Tract and Longleaf Tract, Palustris Experimental Forest . . Inside back cover 


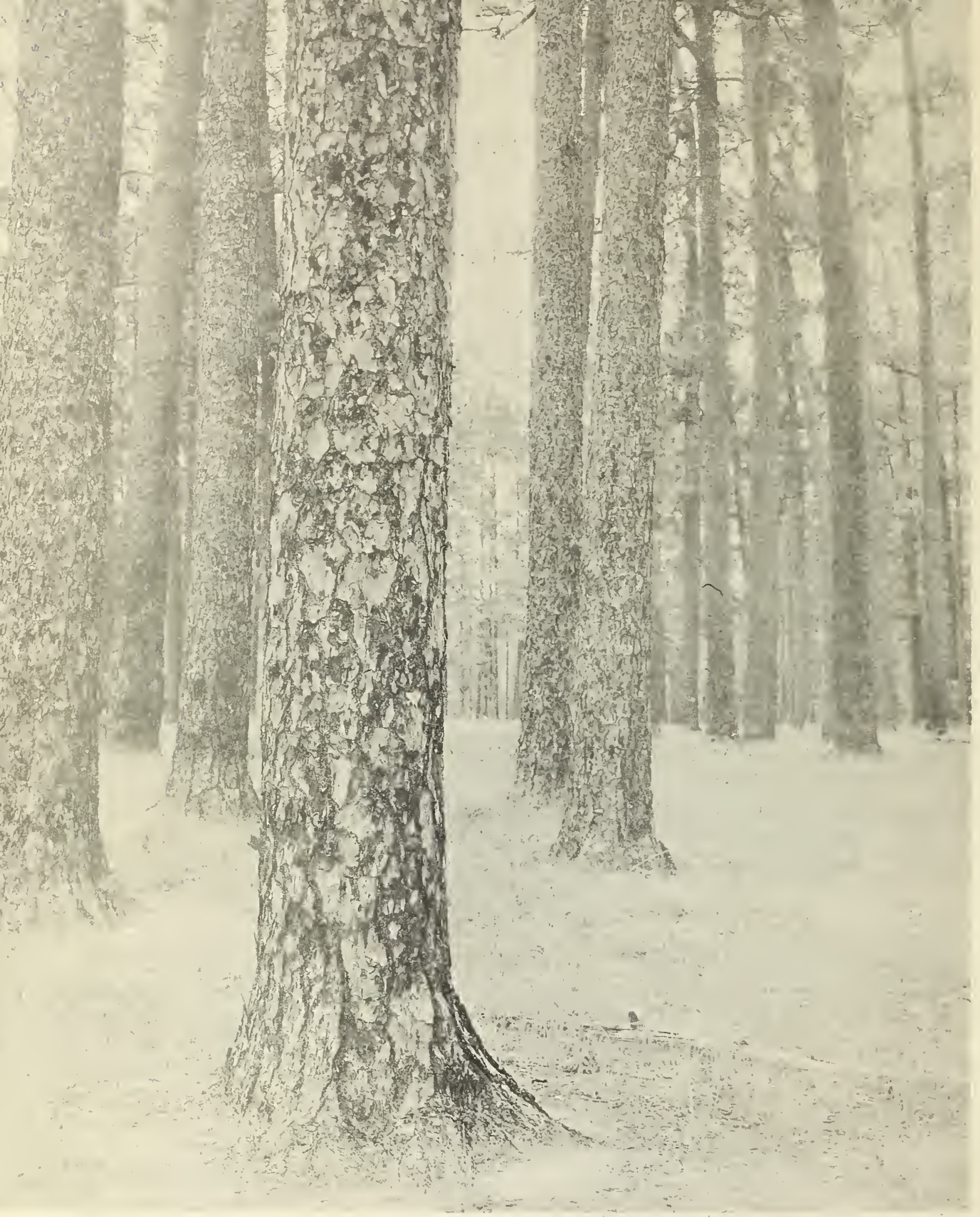

Figure 2. --Virgin longleaf pine near Turkey Creek, Louisiana. Only a remnant of such timber is left. (Photo by Kohara Studio) 


\section{THE ALEXANDRIA RESEARCH CENTER}

John T. Cassady and William F. Mann, Jr.

Most of the land in the territory served by the Alexandria Research Center is better suited to growing timber than to any other use. This means that the development and prosperity of the region depend vitally upon improved forest management. The most pressing need is to get the huge area of cutover land back into high production quickly and at a reasonable cost. This step alone would triple the region's pine timber production.

The territory in question covers $7,141,000$ acres in central and southwestern Louisiana and east Texas (fig. 1). Almost 80 percent, or $5,664,000$ acres, is commercial forest land, and less than 10 percent is cultivated. About half of the forest land once, supported magnificient stands of virgin longleaf pine (fig. 2), and the whole region is now sometimes called the cutover longleaf pine belt. The other half of the forest is divided between loblolly and shortleaf pine and upland and bottomland hardwoods.

Over 20 percent of the forest land, or 1,250,000 acres, is barren of trees and mustbe planted with pine if it is to be restored to timber (fig. 3). About 3,000, 000 acres of timber land are producing much below full potential because scrub oaks and other low-value hardwoods are over-abundant and the pine stand is inadequate.

Upland soils are too shallow, poorly drained, or infertile for farming. Numerous hill farms have been abandoned or converted to pastures and headquarters for range livestock operations (fig. 4). The good agricultural land is in the flood plains of the major streams, and here new farms are still being created by clearing and draining the land. Thus, the acreage of bottomland hardwoods is decreasing. 


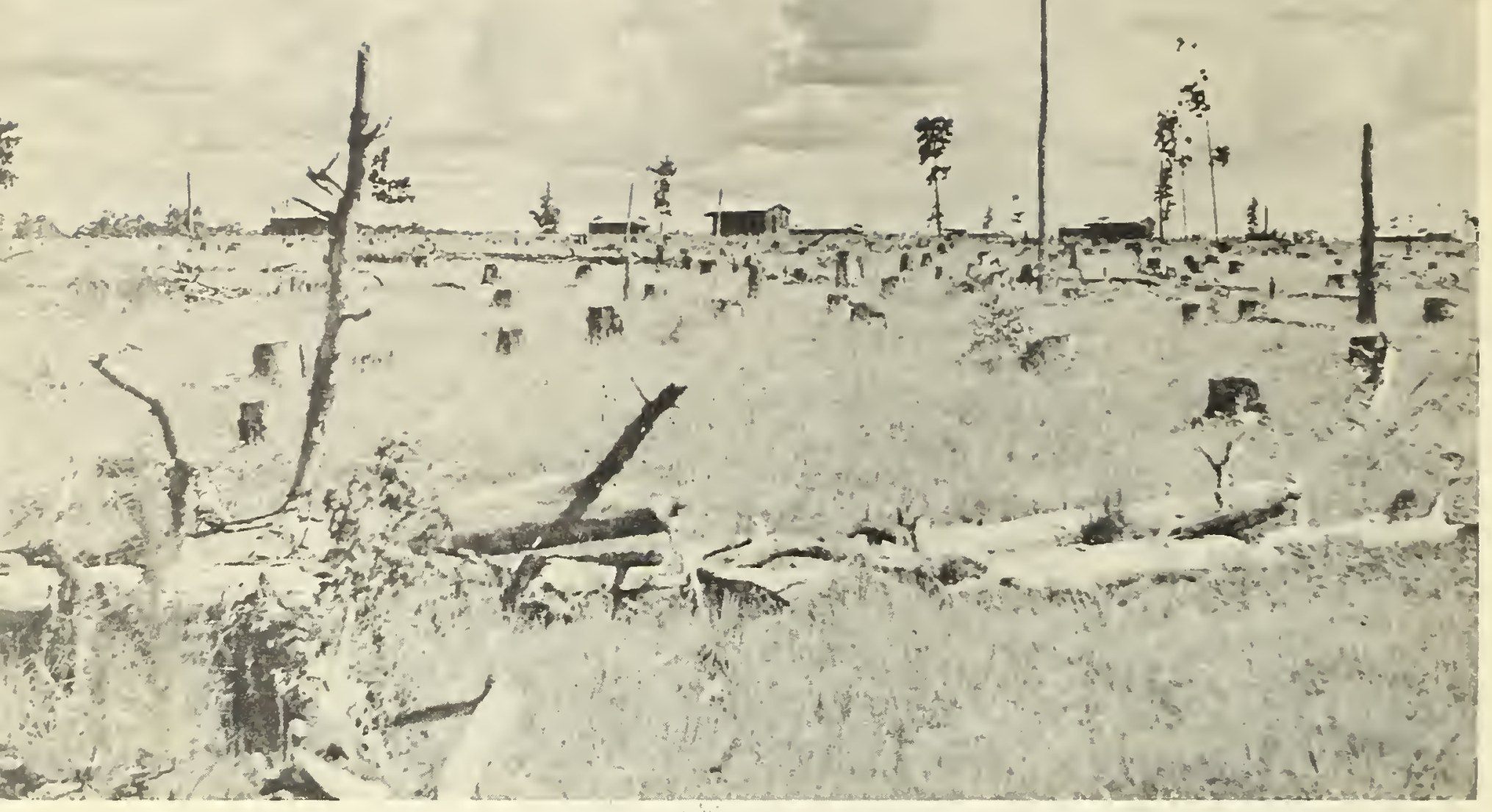

Figure 3.--More than a million acres of barren forest land need to be planted or seeded with pine trees.

Figure 4. --Most hill farms in the cutover longleaf pine belt have either been abandoned or converted to semi-improved pasture.
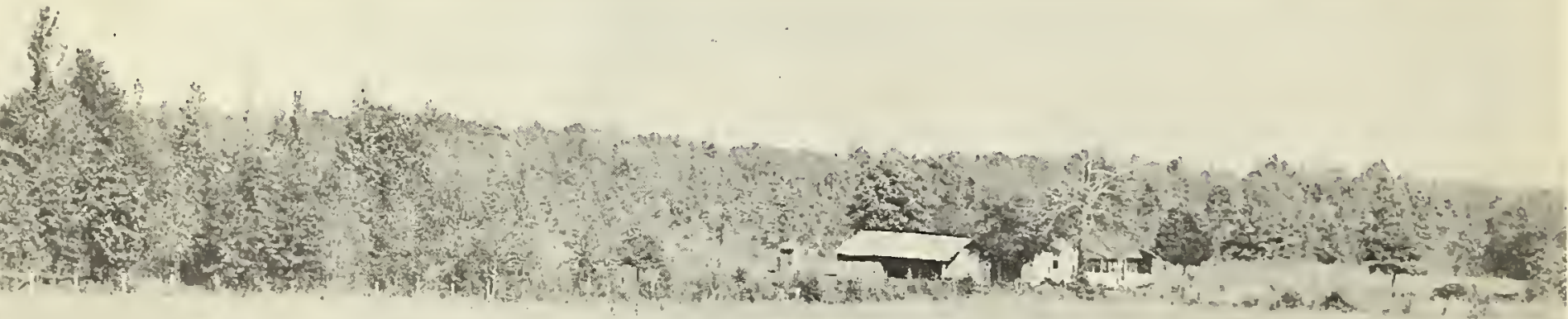

(n)

4. $1 . \min$

R.

40 
The cutover pine lands support an abundant stand of native grasses, and range livestock grazing is an important industry. The grass is nutritious in spring and early summer, but decreases in value as the year advances. Grazing is mostly conducted on the free range principle. Most of the range is unfenced and all kinds and grades of stock graze together. Under this system the individual owner has little control over his own or his neighbor's animals and therefore finds it impractical or impossible to improve his herd by breeding, by feeding when range forage is poor, or by practicing good herd management generally.

The mission of the Alexandria Research Center is to develop improved methods of reforestation and management to guide forest landowners in the task of attaining optimum production and income. When the Center was established in 1946, its first step was to study the forest situation in the area and to propose a research program to its Research Advisory Committee. This group selected, as most urgent, these five lines of investigation:

1. Reforesting the cutover pine lands.

2. Managing pine plantations for optimum returns.

3. Controlling low-value hardwoods with chemicals.

4. Improving management of livestock and forage on forest ranges.

5. Determining costs and returns of good forest management.

The progress that has been made in these research projects is described in the following pages. 


\section{REFORESTING THE CUTOVER PINE LANDS}

If landowners are to restore their forests to production quickly and efficiently, research will have to find the answers to many troublesome questions.

Under what conditions is it most profitable to plant slash pine? Longleaf pine? Loblolly pine? How can planting techniques be improved to attain better survival and growth? Can selection or crossbreeding develop new pine varieties that will be easier to grow and more productive? The cost of planting nursery seedlings is high; can money and time be saved by sowing pine seed directly in the field? Where pine seed trees are left, how can they be made to restock the land fully and quickly? What is the most efficient system of converting the vast acreage of scrut hardwoods to pine?

\section{Choice of Species}

Since most of the acreage that now needs restocking was once covered with nearly pure stands of high-quality longleaf, it would seem natural to plant or seed this species again. The trouble is that longleaf is hard to get established, while loblolly and slash pine are easy to plant and grow vigorously on many former longleaf sites. Accordingly, many landowners have turned to loblolly and slash, despite the fact that young trees of both species are highly vulnerable to fire.

Slash pine, which does not naturally occur west of the Mississippi River, has enjoyed the greatest popularity (fig. 5). Recently, however, heavy damage from ice storms and the southern fusiform rust (Cronartium fusiforme) have caused some landowners to switch to loblolly for well- drained sites.

Loblolly vs. slash in plantations. - Studies confirm that loblolly is the better species on average or better sites that are well drained. In one 23-year-old plantation, the loblolly trees were 2 feet taller and 1 inch larger in diameter than slash. The loblolly yielded 4 cords more pulpwood per acre than the slash. Nearly 25 percent of the slash pine had rust cankers on the trunk; loblolly had almost no trunk cankers. Ice damaged about 50 percent more slash than loblolly pines. 


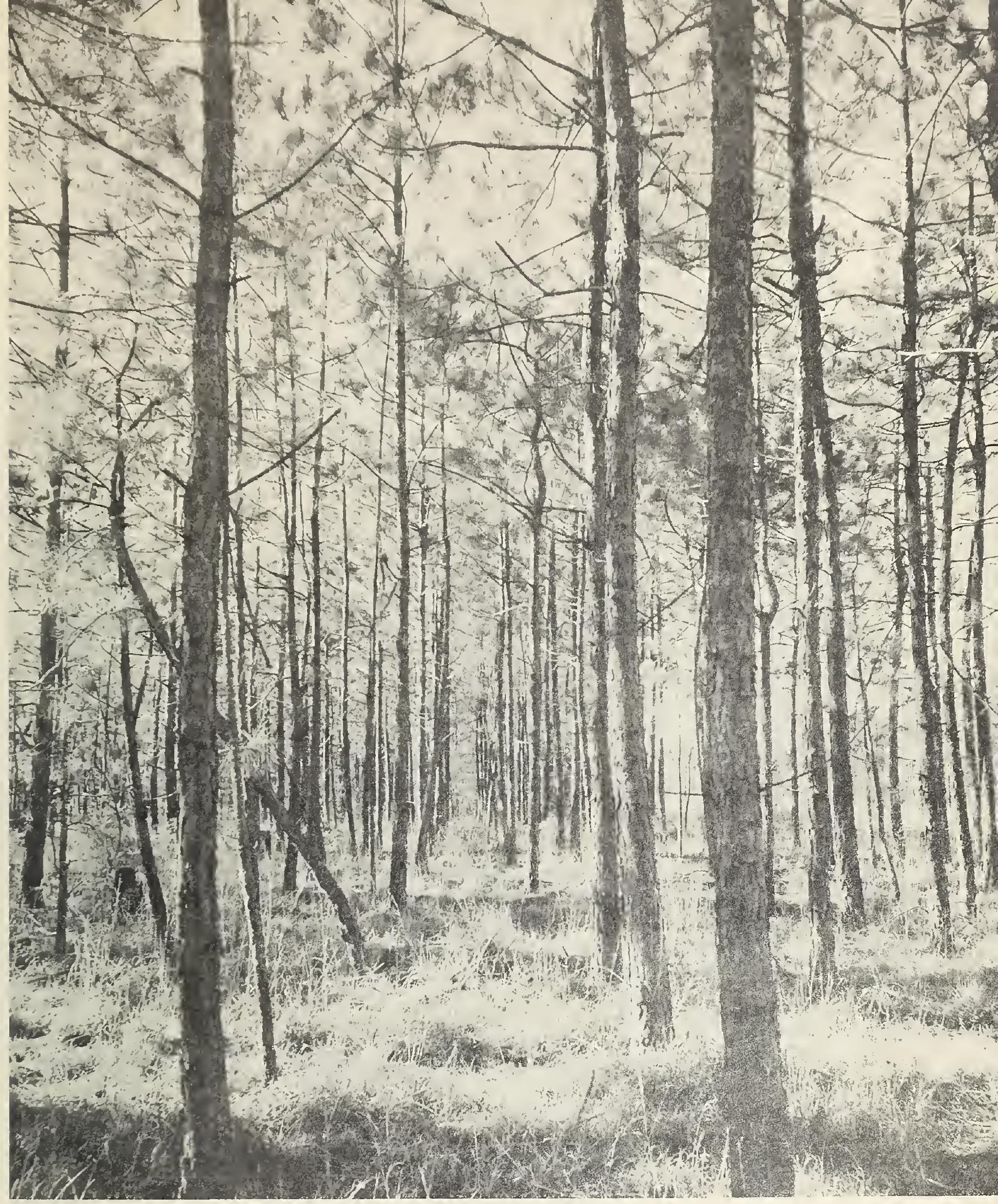

Figure 5. - About 100, 000 acres of denuded land in central Louisiana have been planted to slash pine. Is it the best species to plant? The plantations have suffered from wildfire, ice storms, and southern fusiform rust, but most of them still have a fairly good stand of trees. (Photo by Elemore Morgan) 
This plantation is now being studied to learn if the early advantage of loblolly will be maintained.

Slash pine also has distinct values. It yields gum for the naval stores industry and ordinarily produces a straighter pole than loblolly. On poorly-drained soils it is unquestionably superior in growth and form to loblolly. Evidence is accumulating, too, that damage from ice and fusiform rust can be lessened by planting the trees at a spacing of 6 by 6 feet $(1,200$ trees per acre) and keeping the stand dense as it develops. In a 13-year-old slash plantation, rust cankers were found on 19, 14, 13, and 11 percent of the trunks of trees planted at the rate of $190,795,1,005$, and 1,515 per acre, respectively. Ice damage was also less severe in the close spacing and the lightly thinned stands.

Development of natural stands of slash pine. - - Will heavily stocked natural stands of slash pine resist disease and ice better than planted stands? To answer this question, a 250-acre plantation, severely damaged by fires and ice storms, has been divided into 9 plots and cut back to 70 seed trees per acre. When 2,000 or more well-distributed seedlings per acre are obtained, the overstory trees will be further reduced: three plots will be left with 5 overstory trees per acre, three with 10 trees, and three with 20. On half of each plot the overstory will be removed when the seedlings reach a height of 12 feet and can be prescribeburned. On the other half, the overstory will be retained until the first thinning is made at age 15 .

This study will help guide landowners in the future management of the 100,000 acres of slash plantations already started in this area. Although they have been damaged by wildfire, ice, and disease, many of these plantations still are reasonably well stocked with pole-size trees of good form.

\section{Stimulating Longleaf Height Growth}

Regardless of the trend toward other species, some landowners continue to plant longleaf on the cutover lands. Once it is established, longleaf has some outstanding advantages. First of all--as evidenced by the original stands--it will grow successfully on the rather dry, sandy upland solls that cover much of this area. This ability to succeed where other pines fail arises from longleaf's superior resistance to wildfires and the fact that it suffers very little from disease after it reaches 5 or 6 feet in height. Longleaf also produces clean, straight poles and sawlogs of high quality. 
Most of the disadvantages of longleaf belong to the seedling stage:

Planting costs are higher than for the other pines.

First-year survival is comparatively low.

Young stands must be fenced to protect them from woods hogs. Even under good conditions, longleaf seedlings usually require at least 3 years to start height growth. The brown spot needle disease often keeps them "in the grass" for several more years, causing los of growth and further mortality.

If longleaf is to be planted successfully, methods must be found to improve survival and stimulate early growth. The most practical means of stimulating height growth of longleaf seedlings is carefully controlled grass fires that check brown spot disease.

In a 100-acre experimental longleaf plantation started in 1934-35, plots that were burned at 3 and 6 years of age to retard brown spot infection now have twice as many trees in active height growth as unburned plots. Even on the burned plots, however, only 20 to 25 percent of the original seedlings survived and began growing. Studies were started in 1949 on the Johnson Tract to find a more satisfactory method of stimulating height growth. In the first experiment, longleaf seedlings were planted on replicated quarter-acre plots, each having one of these site treatments:

Grass burned before planting

Soil disked before planting

Grass burned and soil disked

Furrows plowed with a fireline plow

Old grass rough--no ground preparation.

Each plot was split into four quarters. Seedlings on one quarter were sprayed with bordeaux mixture and fertilized with an N-P-K mixture. The other quarters got one of these treatments: spray but no fertilizer, fertilizer but no spray, no fertilizer or spray.

After four years, seedling survival was unusually high on all plots and had not been increased by any site treatment. Above-average rainfall favored high survival. Sprayed seedlings were larger and more vigorous than unsprayed. However, the early advantage gained by spraying was not great; 54 percent of the sprayed seedlings were making height growth, as against 40 percent of the unsprayed. The fertilizer did more harm than good except where seedlings were planted in 


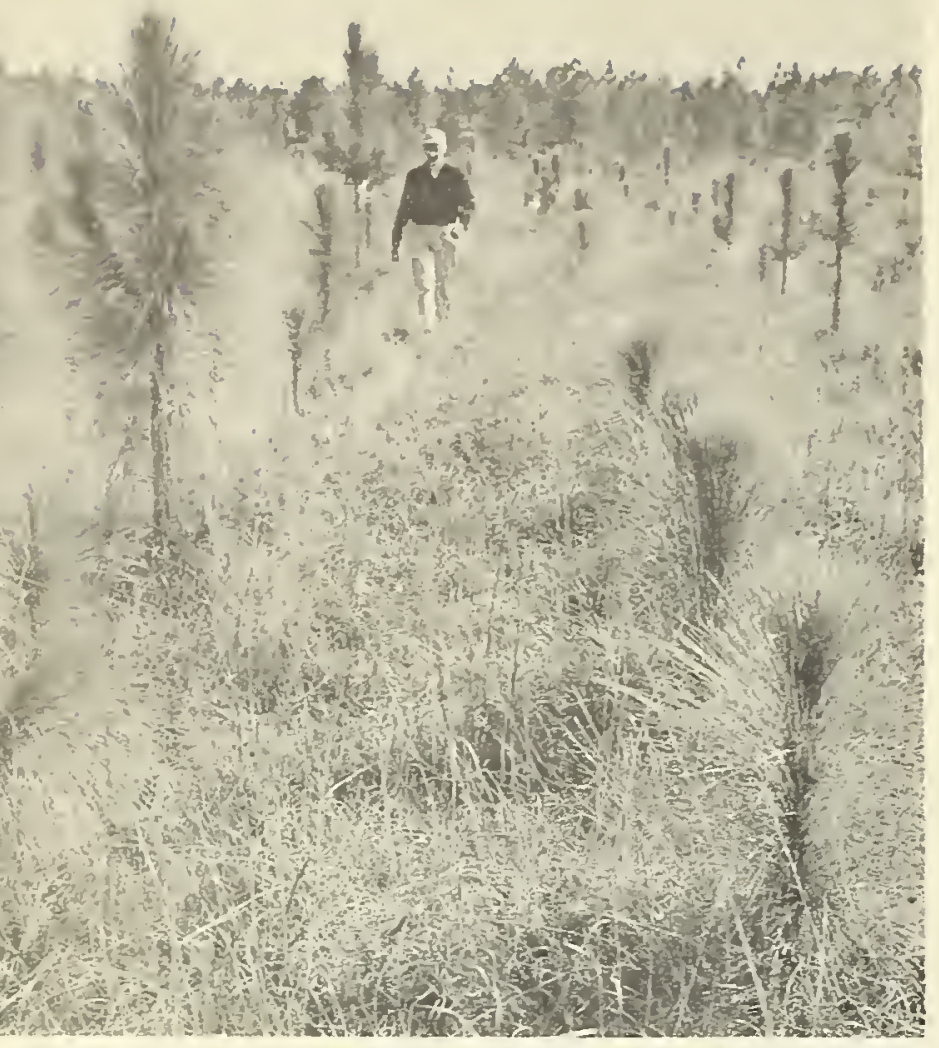

Figure 6. - The se longleaf pine seedlings were planted 5 years ago. The largest ones (row to left) were sprayed with bordeaux mixture to control the brown spot needle disease. (Photo by Elemore Morgan) furrows. It caused a rank growth of weeds and grasses that retarded the pine seedlings. Seedlings developed best on furrowed plots that were sprayed and fertilized; 71 percent of the seedlings were making height growth after 4 years (fig. 6). The benefits of disking and furrowing were lost on unsprayed plots because brown spot infection built up more rapidly than on the uncultivated plots. The seedlings planted in the grass rough and given no other treatment were remarkably successful in this test--over 50 percent were in active height growth after 4 years.

Another study is testing the effect of clipping the needles on longleaf planting stock or dipping them in wax. The object is to reduce water losses through the needles until the roots can recover from transplanting. So far it appears that clipping the needles to

a length of 5 inches distinctly improves survival in a dry year. Dipping the needles in wax or other substances has sometimes increased survival and sometimes reduced it.

Since large nursery seedlings often start height growth earlier than small ones, special tests are under way on the production and planting of extra large seedlings. An attempt is also being made to find the best age to burn longleaf seedlings for disease control. Observations indicate that the first burn should be made 2 years after planting rather than 3 years.

\section{Direct Seeding}

If all of the treeless longleaf land in Louisiana and Texas were reforested by planting 1 -year-old nursery seedlings, the job would take 50 years or more at the present rate. Because direct seeding promises to be cheaper, faster, and more effective than planting, it has become a 
main project of the Alexandria Research Center. Since 1947, about 3, 000 acres have been direct-seeded in experiments or tests with longleaf, loblolly, and slash pine. No sure-fire method has been found, but major causes of fallure have been identified and work has been concentrated on controlling or avoiding these causes.

Seed-eating birds, chiefly meadowlarks and sparrows, are the greatest obstacle. Coating the seeds with a repellent seems the likeliest solution, and some chemicals now being tested show promise (fig. 7). Rodents, another menace to seeds, can usually be controlled by burning the grass rough. Reduction of the rough also insures that the seeds will reach mineral soil. Burning should be done at least six months before seeding, because fresh burns attract birds.

Longleaf. - Research so far indicates that the greatest chance for success in direct-seeding longleaf pine will be obtained by this procedure:

1. For average sites: Burn the grass rough at least 6 months before seeding time. The light rough that will develop after the burn will be a favorable seedbed. On dry sites, or for insurance against a dry season: Burn the grass as above, and also disk during the summer before seeding to lessen grass competition. To reduce costs, the disking should be in strips 6 to 8 feet wide and 6 feet apart, and seeding should be confined to the cultivated strips.

2. Sow seed in November as soon as autumn rains begin and temperatures are under $80^{\circ} \mathrm{F}$. Sowing after November is not recommended, because the chance of heavy seed losses to migratory birds is much greater in December.

3. Sow 10,000 viable seeds per acre. This means about 3 pounds per acre of longleaf seed of average quality. Seed must be tested to determine viability and the amount required per acre. The seed can be broadcast by hand or with hand-operated cyclone seeders (fig. 8). Airplane sowing has not been satisfactory so far because of higher costs, poor seed distribution, and delays during bad flying weather. 


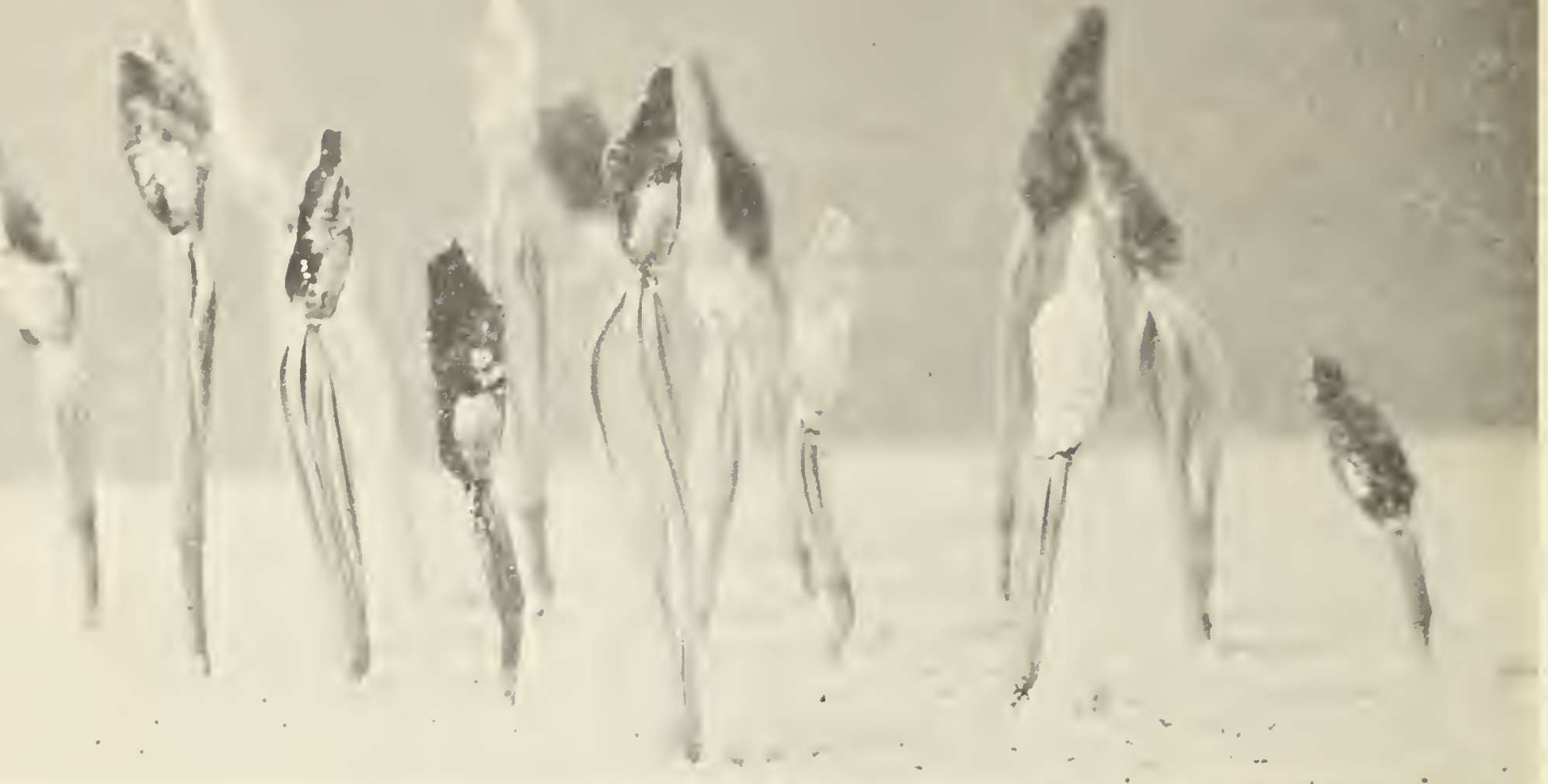

Figure 7. - These germinating longleaf seeds were covered with various chemicals or coating $s$ in an attempt to find a substance that would repel birds. (Photo by Elemore Morgan)

Figure 8. -- With a cyclone seeder, one man can sow 30 acres to pine in 8 hours. (Photo by Elemore Morgan)

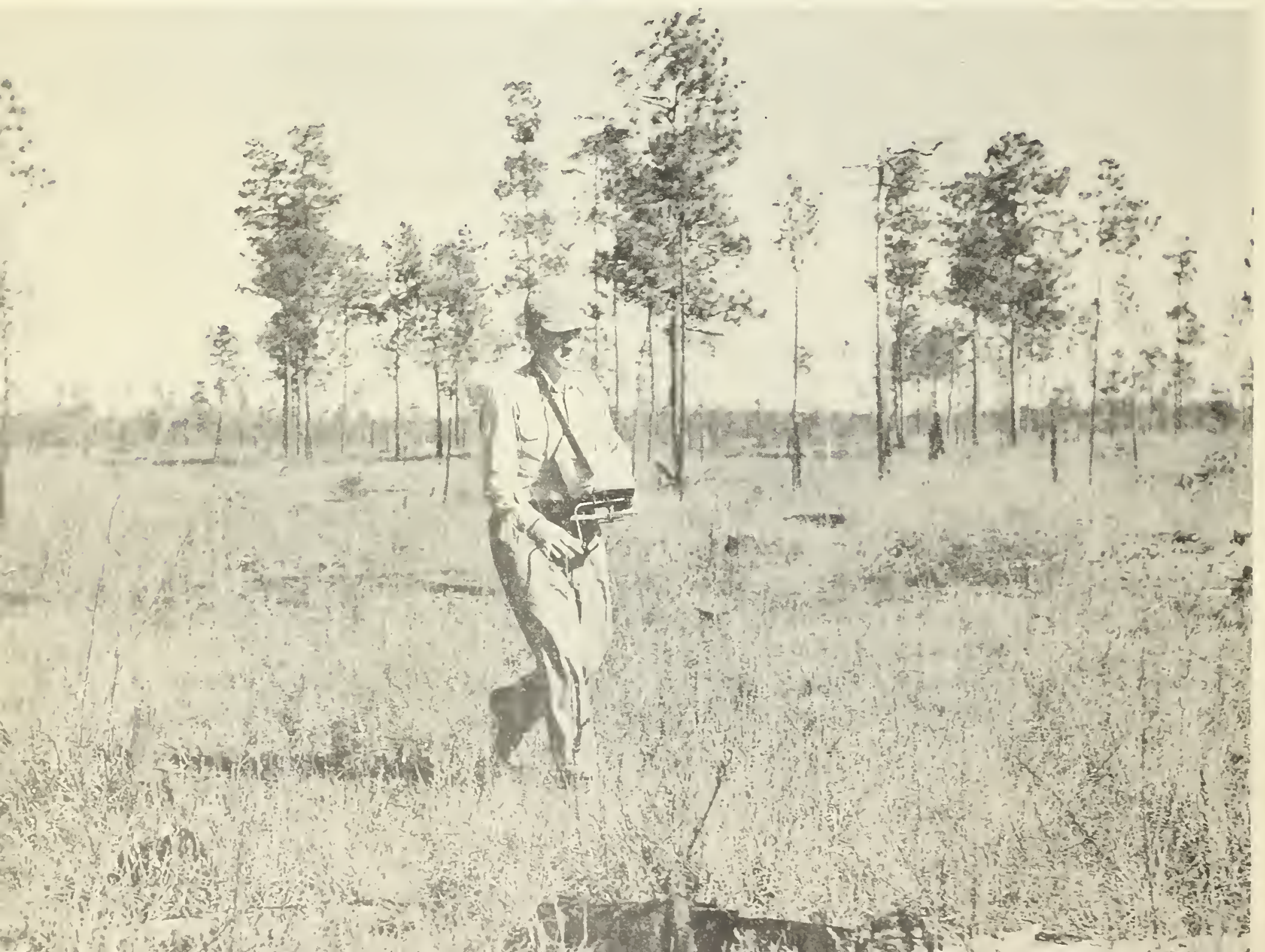


4. Patrol the seeded area each day for several weeks, especially during very early morning and late evening, to prevent bird concentrations and to detect other animals that may be destroying seeds. Special control measures can be undertaken if needed. Grazing animals should be excluded for several years, or until the seedlings are high enough to escape trampling and browsing damage.

The total cost of seeding has run from $\$ 4.50$ to $\$ 8.00$ per acre, depending on the type of seedbed, the price of seed, and the method of distributing it. In contrast, it costs $\$ 10$ to $\$ 16$ per acre to plant longleaf seedlings $(1,200$ per acre) on nearby areas of the Kisatchie National Forest.

Loblolly. --Techniques for direct-seeding loblolly pine vary with cover conditions. So far the best procedure for open grassy areas is to burn the grass in April or May, and then, in late summer, to disk strips 6 to 8 feet wide and about 6 feet apart.

From the experience of the Alexandria Research Center, it appears that seed should be cold-stratified for about 90 days at $35^{\circ} \mathrm{F}$. so that it will germinate promptly. (Tests of individual lots of seed, however, may indicate different treatment.) The seed should be sown in late February or early March, on disked strips, at the rate of 1 pound per acre. Since seedlings that germinate in fall are killed by freezing weather, fall sowing has not been successful. Disking is necessary because the newly germinated seedlings are unable to compete with the grass.

On upland sites dominated by low-grade hardwoods, the best method so far is to sow one pound of unstratified seed per acre on a fresh burn in early November. The seed will not germinate until spring, and falling leaves will conceal most of it from birds and rodents.

Slash.--Slash pine seeding studies have not yet reached the point where recommendations can be made. However, it has been determined that slash seedlings can withstand freezing temperatures and can come through on undisked grassy areas. This may mean that slash can be sown in the fall, when both birds and rodents are less of a problem than in the spring. 
A considerable portion of the cutover longleaf pine area supports scattered seed trees singly or in groups. Natural reseeding has failed, in many cases, because good seed years have been few and far between. There is hope, however, that these seed trees can be made to yield larger and more frequent seed crops. The following treatments are under test with both longleaf and slash pines:

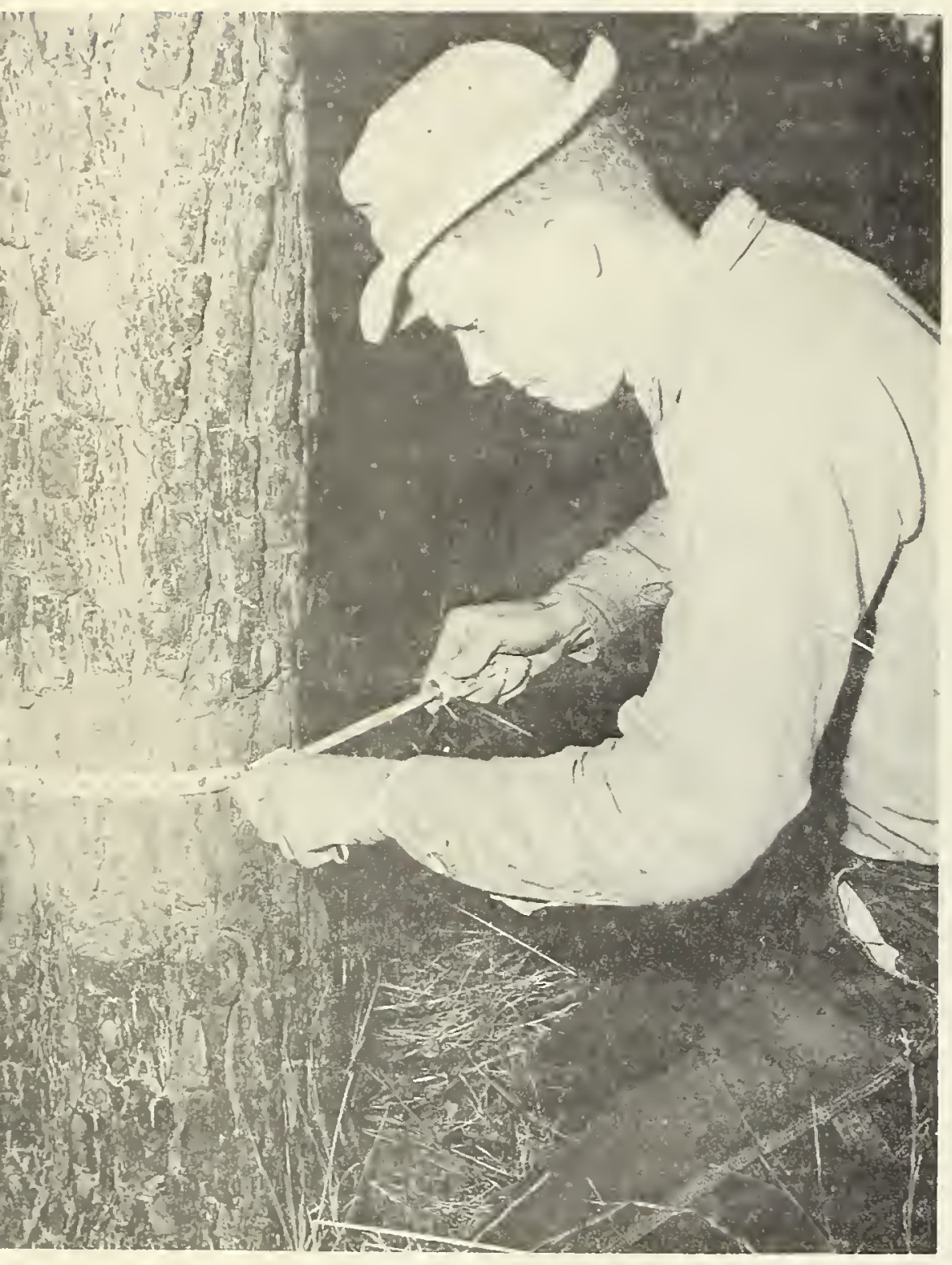

Figure 9.--Fastening a tight metal band around the tree at stump height seems to stimulate cone production. (Photo by Elemore Morgan)
Partial girdling. Two half rings are cut around the tree down to the wood. The rings are about 1-1/2 inches wide and are placed on opposite sides of the trunk, one about 4 inches higher than the other.

Strangulation at stump height. A tight metal band is bolted around the tree about 12 inches above the ground (fig. 9).

Strangulation high on the bole. Metal bands are bolted around the tree in or just below the live crown.

Hormone treatment. A 0.2-percent solution of $2,4-D$ is put into an intermittent frill around the tree about 2 feet above the ground.

The first three of these treatments have been used with success in Europe. The hormone treatment is new. The study was installed in 1952. 
Many upland sites have been taken over completely by scrubby hardwoods--very little or no pine is left. These areas produce no timber and have low grazing value. A study installed in 1948 on the Kisatchie National Forest shows that they can be converted back to pine quickly and at a reasonable cost.

Loblolly, slash, and longleaf seedlings were planted at 6-foot intervals under a fairly dense stand of inferior upland oaks. The oaks were then girdled or poisoned to release the pines. Some plots were released immediately after planting, some one year later, and some two years later.

Hogs destroyed the longleaf seedlings after the first year, but the slash and loblolly plots showed that both survival and height growth are improved if the pines are released by hardwood control soon after planting (fig. 10). The longer release is delayed, the poorer will be the survival and development. Table 1 shows results three years after planting.

Figure 10.--These 5-year-old loblolly pines are growing on a site formerly dominated by worthless hardwoods. (Photo by Elemore Morgan)

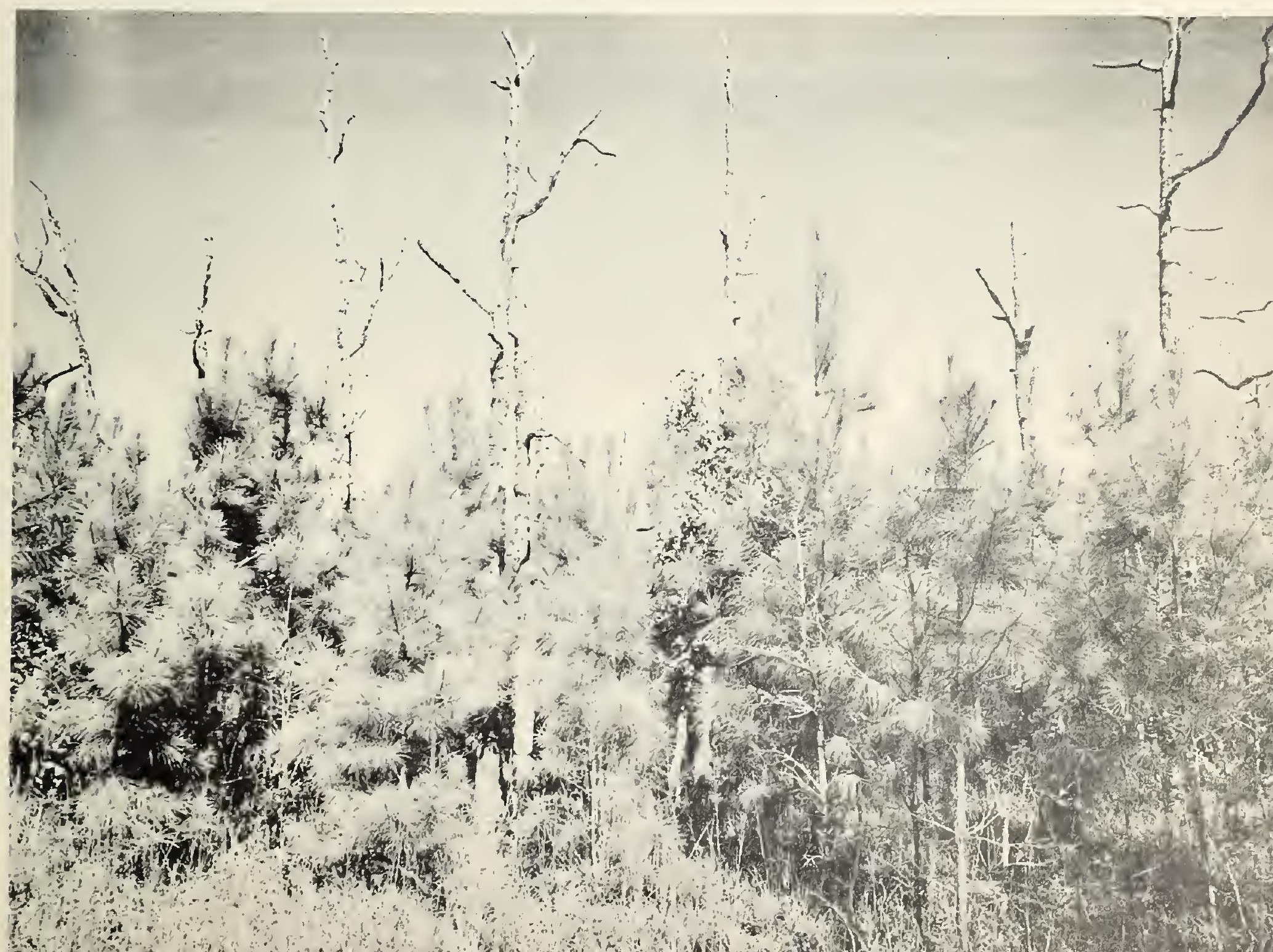


Table 1.--Three-year survival and height growth of pine seedlings released from overtopping scrub oaks

\begin{tabular}{|c|c|c|c|c|}
\hline \multirow[b]{2}{*}{ Time of release } & \multicolumn{2}{|c|}{ Loblolly pine } & \multicolumn{2}{|c|}{ Slash pine } \\
\hline & Survival & $\begin{array}{c}\text { Average } \\
\text { height }\end{array}$ & Survival & $\begin{array}{c}\text { Average } \\
\text { height }\end{array}$ \\
\hline & $\underline{\text { Percent }}$ & Feet & Percent & Feet \\
\hline Immediately after planting & 86 & 4.3 & 46 & 3.4 \\
\hline One year after planting & 62 & 3.2 & 36 & 2.3 \\
\hline Two years after planting & 39 & 2.5 & 31 & 2.1 \\
\hline Not released & 33 & 2.2 & 27 & 1.6 \\
\hline
\end{tabular}

Girdling was as effective as poisoning in removing the oaks and releasing the pine. Girdled trees sprouted more than poisoned ones, but the pines outgrew the sprouts. Therefore, the cheapest method of release is recommended. Other studies have indicated, however, that where longleaf is being released, poisoning is necessary to prevent the hardwood sprouts from resuppressing the seedlings before they are out of the grass stage.

The pines that were released immediately after planting survived well during 1948. In contrast, the severe drouth of $1948 \mathrm{killed}$ nearly all seedlings planted in adjacent open areas. Survival was good in 1948 because there was very little competition for available moisture --the hardwoods were dead and the grass stand under the hardwoods was only one-third as heavy as that in the open. The benefits of this reduced competition continued for at least 3 growing seasons. By then the pine trees were well established and above the grass.

\section{Forest Tree Improvement}

The Alexandria Research Center is participating in a South-wide genetics program that seeks to breed fast-growing, well-formed, disease-resistant pines, including hybrids. Work at Alexandria is concentrated on crossing trees that possess outstanding characteristics. One such tree is a longleaf pine that, as a seedling in the nursery, displayed high resistance to brown. spot infection. Now that it is large enough to produce cones, its flowers are being carefully self-pollinated. Seedlings from this tree will be watched to see if they also can withstand brown spot. 


\section{MANAGING PINE PLANTATIONS FOR OPTIMUM RETURNS}

By 1954, the Alexandria area already had 160,000 to 180,000 acres of pine plantations; 15,000 to 25,000 acres more are being planted each year. Since pine tree planting requires an investment of $\$ 7$ to $\$ 16$ per acre, it is essential that landowners manage plantations so as to provide early, high, and sustained income. They especially need to know:

1. When the first thinning should be made.

2. How heavily to thin for various management objectives.

3. The type of trees to retain in stands being managed for maximum growth of high-quality sawtimber.

4. The feasibility and best system of pruning in understocked stands.

5. How and when to prescribe-burn for brown spot control or hazard reduction.

6. How to minimize damage from wildfire, insects, disease, and storms.

\section{Thinning Loblolly Pine Plantations}

A thinning study in cooperation with the Louisiana Forestry Commission was started on the Alexander State Forest in 1948. The study tract is 40 acres of loblolly pine planted in 1928 at four different spacings ( 4 by 4,6 by 6,8 by 8 , and 10 by 10 feet). Light, medium, and heavy thinnings were made in each spacing when the trees were 20 years old and again at age 25. Unthinned plots were left in the three widest spacings to determine results of future deferred thinnings. The thinnings will be repeated every five years.

The medium thinnings at age 20 took out about 11 cords per acre. The wood sold for enough to repay, with interest, all previous costs of planting, protection, and land rent. Total growth was greatest in the 8 by 8 spacing, which had 29.5 cords per acre or an average of $1-1 / 2$ cords per acre per year.

At age 25, the 8 by 8 spacing showed a total average yield (including the wood removed in thinnings) of 39 cords per acre. This was slightly more than the total growth on the other spacing blocks. Because 
there is only one plot ( 10 acres) of each spacing, the test cannot prove the superiority of any one spacing. However, the 4 by 4 spacing is obviously too close. Planting costs were excessive and many trees have been lost by overcrowding. Those trees that remain are small and are slow in reaching merchantable size. Each of the other spacings shows some advantages, but the 8 by 8 appears superior for maximum growth (fig. 11).

The greatest volume growth for the period 20 to 25 years of age was made on the unthinned plots--those that supported the highest basal areas or stand densities. Even the light thinning showed reduced volume growth, but not so much as the heavy thinning. Furthermore, experience with natural loblolly stands suggests that the unthinned plots or densest stands will continue to produce the most wood until about age 35. It seems, therefore, that if loblolly pine plantations are being managed for maximum production of pulpwood on a short rotation, they should not be thinned at all.

Figure 11. - - The 8 by 8 loblolly plantation after the second medium thinning. Enough well-spaced trees are left for an early crop of sawlogs.

(Photo by Louisiana Forestry Commission)

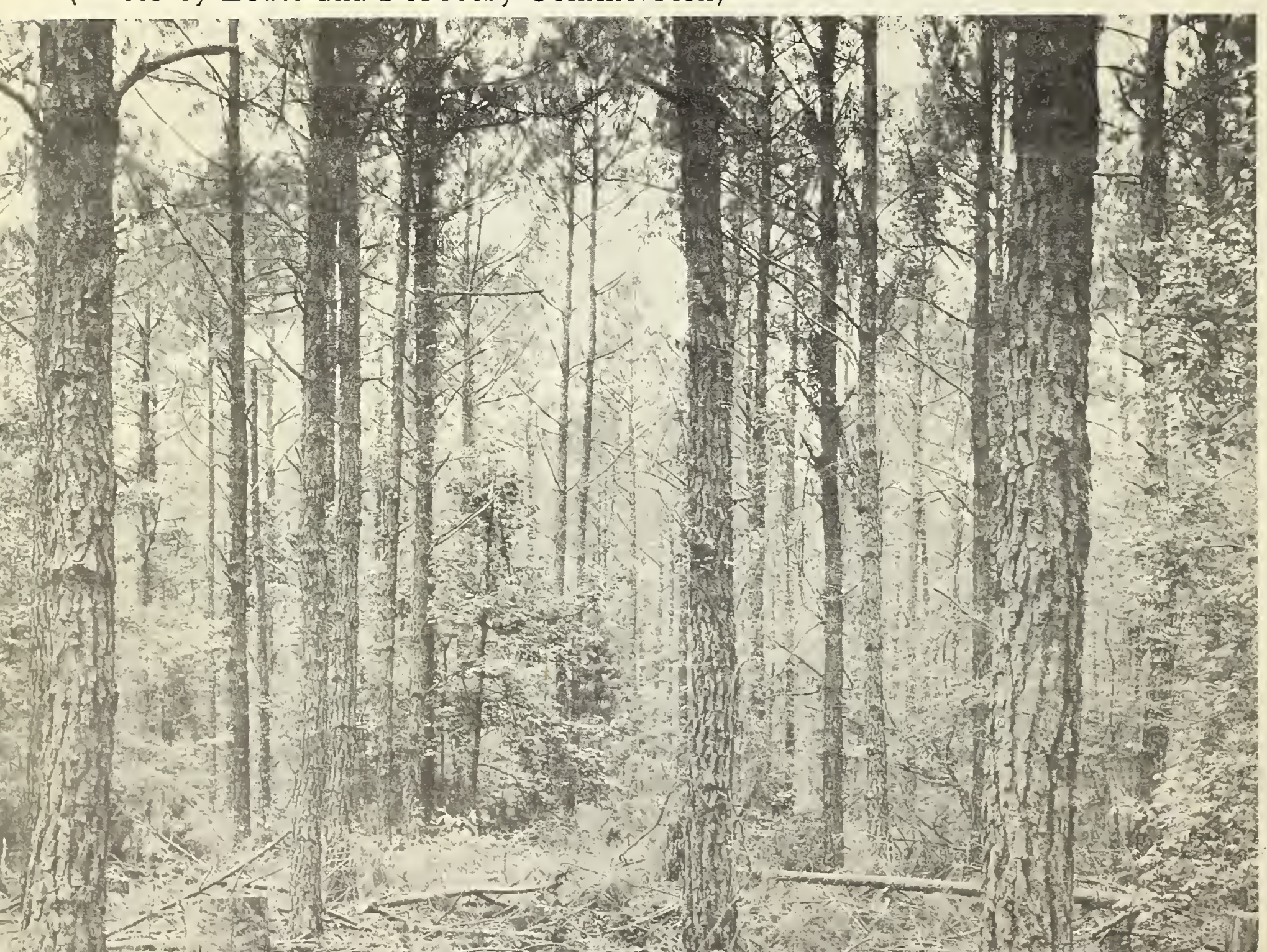


But when sawlogs or other large products are being grown, timely thinnings are desirable. In this study, the heaviest thinnings not only produced the fastest diameter growth but also concentrated it on selected crop trees. The heavy thinnings will give comparatively early production of large poles, piling, and sawlogs. It is of interest that the best rate of growth was around 2.5 inches in 10 years even on widely spaced and heavily thinned plots where trees had more than half their height in live crown. This is a bit short of the oft-advocated goal of 3.0 inches of diameter growth in 10 years.

To stimulate diameter growth, thinnings must be heavy (fig. 12). However, when heavy thinnings are made, volume growth per acre is reduced. During the 5 years between cuttings, the heavily thinned plots in this study forfeited 3 cords of pulpwood growth while gaining only an extra 0.35 inch of diameter growth.

\section{Management of Longleaf Plantations}

A 100-acre longleaf pine plantation was established in 1934-35 on the Johnson Tract for a study of spacing, prescribed burning, pruning, and thinning.

On 60 acres, seedlings were planted at rates of $250,700,1,150$, $1,600,2,150$, and 2,500 per acre. This part of the plantation has been protected from fire. On the other 40 acres, seedlings were planted at only four rates--250, 1,150, 1,600, and 2,500 per acre. At 3 years and

Figure 12. - Increment cores taken from the 8 by 8 loblolly plantation when the trees were 25 years old. Heavy thinning was necessary to boost diameter growth. Light thinning merely prevented a decline. (Photo by Louisiana Forestry Commission)
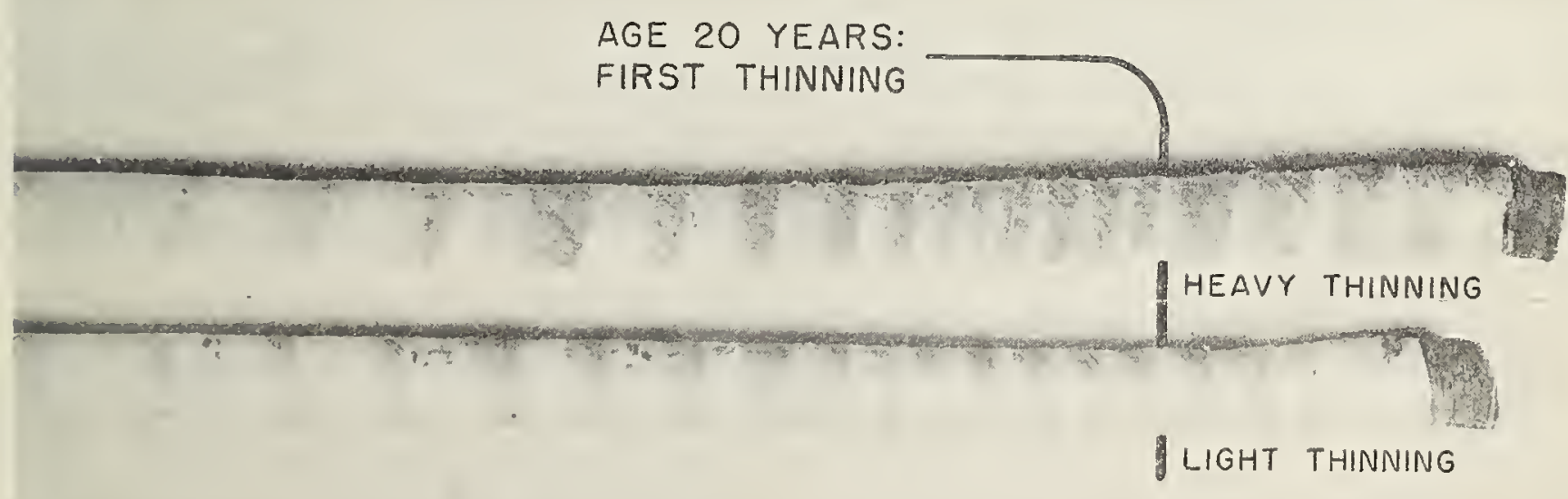


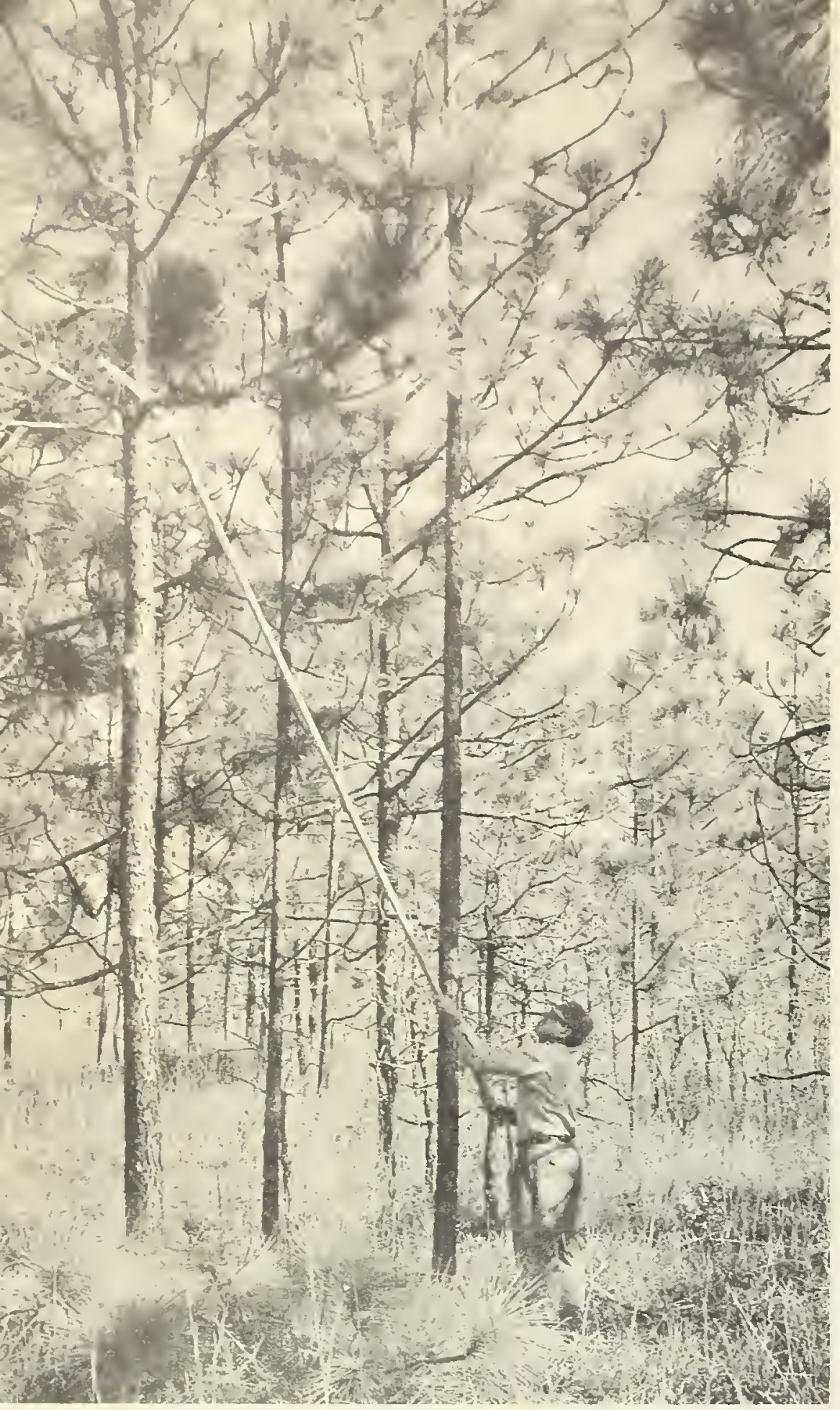

Figure 13.--In open-grown stands, 100 longleaf trees per acre can be pruned to a height of one log for about $\$ 5.50$. (Photo by Elemore Morgan)

6 years after planting, these plots were prescribe-burned to control brown spot needle disease. Wildfires burned over them at 8 years and 17 years after planting. Another controlled burn to remove excess fuel was made in February 1950 , 15 years after planting.

At age 15, there were about twice as many trees in active height growth on the burned plots as on the unburned plots. For example, on areas planted at the rate of 1,600 trees per acre, unburned plots had only 176 trees per acre in active height growth while burned plots had 363. These plots are fairly typical of the difficulties that have been experienced ingrowing planted longleaf. During the first 15 years all plots suffered losses from town ants, hogs that temporarily invaded the fenced plantations, salamanders (eastern pocket gophers), and brown spot. Fires reduced the stands on the burned plots, but not so much as the brown spot infection on the unburned plots.

When the stands were 16 years old, three pruning treatments were applied to a total of 4,800 rough, limby trees in the widerspaced plots: 1. --All trees pruned up to a height of 17 feet ( 1 sawlog); 2. --One hundred selected trees per acre pruned to 17 feet (fig. 13); 3. - - One hundred selected trees per acre pruned to about two-thirds of the tree height.

One-log pruning required 3 man-minutes of labor for a tree 4 inches d. b. h. and 6 minutes for an 8 -inch tree (which usually had larger branches). At 85 cents per hour for common labor and 25 cents per hour for transportation, supervision, and other expenses, pruning costs per tree averaged from 5.4 to 11 . 1 cents. 
Pruning higher than 17 feet was harder and more expensive. It took only 3.3 minutes to prune a 6 -inch tree to $17 \mathrm{feet}$, as compared to 5.5 minutes to prune to 23 feet.

As the trees are cut, a special study will be made to determine if the increased return from pruned trees will repay the investment in pruning. Thinning studies will be started in these plantations in 1955.

\section{Thinning Slash Pine Plantations}

There is considerable evidence that much damage to slash pine plantations is caused indirectly by heavy thinnings or wildfires that leave the stands open. As a rule, fully stocked slash stands have good resistance to both ice damage and fusiform rust.

The only unburned slash plantation on the Johnson Tract has been placed under study to determine if planted slash will produce satisfactory yields of pulpwood, poles, pilings, and sawlogs in central Louisiana. The plantation is 8 acres in size and was planted in 1934-35 at the rate of 1,150 trees per acre (a spacing of 6.25 by 6.25 feet). Because the stand has never been depleted by fire or cutting, it is still relatively dense and will be kept this way by light thinnings at 3-year intervals.

It was first thinned in 1948, when 5.7 cords per acre were removed from a total stand of 14.4 cords. The 1951 ice storm destroyed 1.8 cords that were not salvaged. The second thinning, in 1952, took out 3.4 cords per acre from a total volume of 20.2 cords. Total growth has so far been 25.9 cords per acre in 18 years, an average of 1.4 cords per acre each year. This plantation has suffered insignificant damage from the series of severe ice storms that heavily damaged nearby slash plantations that had been opened up by wildfires. 


\section{CONTROLLING LOW-VALUE HARDWOODS WITH CHEMICALS 1/}

When the virgin pine was harvested, a variety of small hardwood trees and sprouts was left on many areas and immediately started growing and spreading. Today hardwood trees and brush dominate about onethird of the cutover pine land and have encroached heavily on another onethird. In many places they are too thick for pine seedlings to become established. Where pines do get started, they are often smothered or badly suppressed for many years. These upland hardwoods--chiefly blackjack oak, post oak, red oaks, sweetgum, and hickory--have little or no value for timber (fig. 14).

Foresters have found that it pays well to remove or deaden such trees to release pine seedlings for rapid growth. Some range cattle owners are also eradicating the scrub hardwoods, because they reduce the amount of forage and form thickets that interfere with livestock management. In a study on the Longleaf Tract, grass forage increased from about 700 to 1,900 pounds per acre in the first three seasons after a heavy hardwood stand was controlled.

The old-fashioned double-hack girdle is most practical for many hardwood control situations. However, some trees live a year or longer after being girdled. Trees under 12 inches in diameter are apt to sprout vigorously, often sending up several stems to replace the old trunk. For these and other reasons, forest landowners need improved control techniques that will give quick and positive kills, reduce or eliminate sprouting from stumps and roots, and require a minimum of manual labor, especially hazardous ax work. It is also very important that control methods be economical, for they will be applied on hundreds of thousands of acres.

1/ In January 1954, funds and manpower for these plant-control studies were transferred to the Agricultural Research Service of the U. S. Department of Agriculture. The ARS is continuing the work in close cooperation with the Alexandria Research Center. 


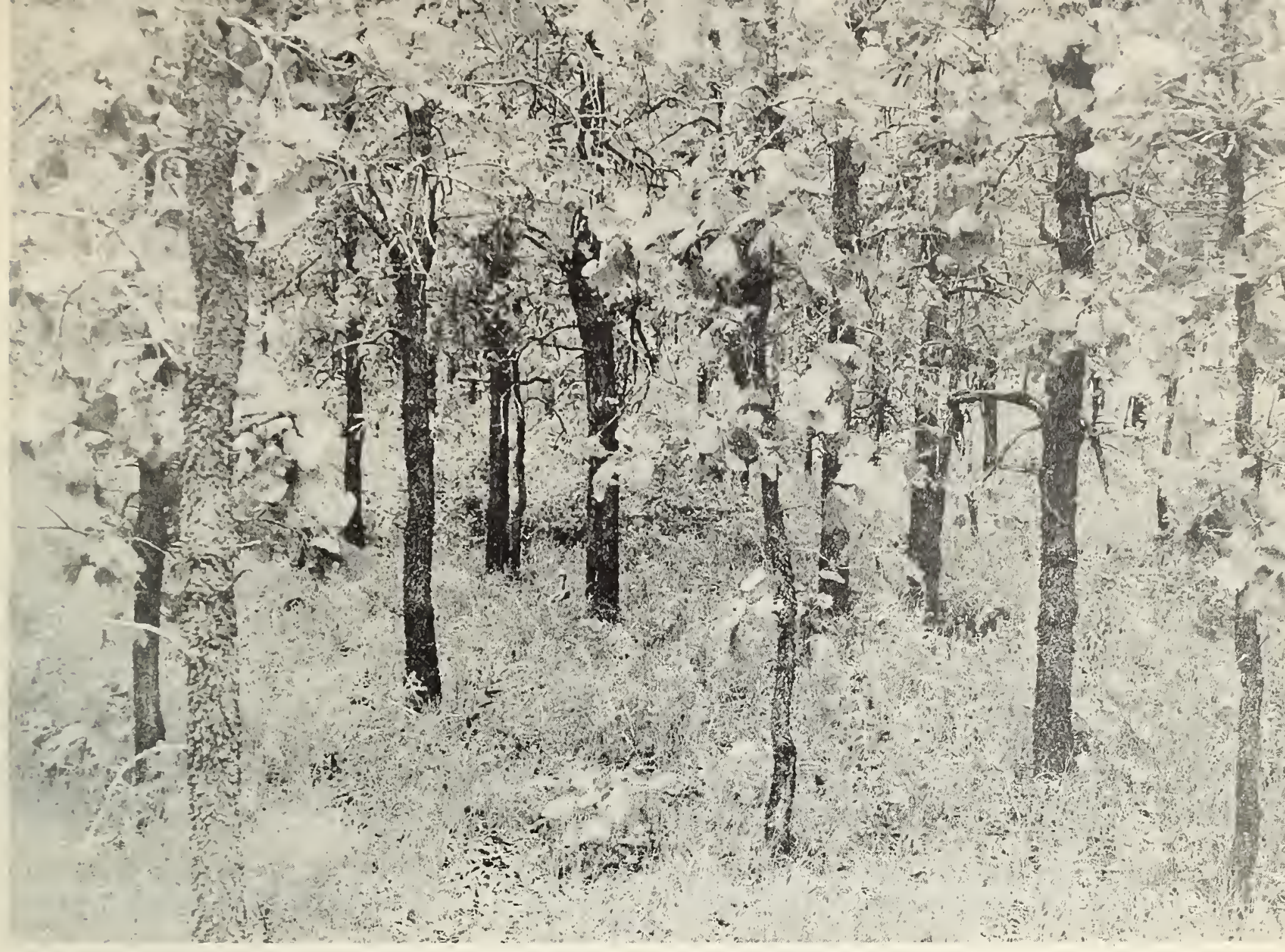

Figure 14. - Unmerchantable scrub oaks have invaded large areas of cutover pine land. Pine planting is needed on some of these areas and hardwood control is needed on all of them.

Since 1944, research has been under way at Alexandria to develop effective methods of controlling hardwoods with chemicals. The Research Center has tested many substances, particularly those not poisonous to humans, livestock, or game. The object is to find the cheapest and most effective tree killers, the best concentrations and seasons of application, and the most efficient methods of getting the chemical into the tree.

\section{Effective Methods Developed}

The first and still the most reliable chemical method developed at Alexandria is that of placing one tablespoon of Ammate (the trade name of ammonium sulfamate) crystals in notches chopped 6 inches apart, edge-to-edge, around the base of the tree (fig. 15A). This method kills scrub oak trees quickly and allows very little sprouting. It 
is being used throughout the United States wherever a quick and positive kill is needed on small or medium-sized scrub oaks. It is less effective on large, tall trees.

The next method developed at Alexandria is that of pouring a water solution of Ammate into a frill made around the tree trunk at a convenient chopping height. A frill is a single-hack girdle that severs the bark and peels it back slightly (fig. 15B). A 19.3 percent solution is recommended; it is made by dissolving 2 pounds of Ammate crystals in a gallon of water.

The frill-and-solution method kills large hardwoods readily and is cheaper and more convenient than the crystal-in-notch system. There is usually some sprouting, but if the pines beneath the hardwoods are at least 1 or 2 feet tall they can usually keep ahead of the sprouts. Many industrial foresters in Louisiana and elsewhere now use this as the standard hardwood control method.

Complete instructions for using Ammate are available in a leaflet, "How to control southern upland hardwoods with Ammate, " published in 1949 by the U. S. Department of Agriculture.

In recent years, many new chemicals have come into use as agricultural weed-killers. The Alexandria Research Center has screened and tested the best of these on scrub hardwoods and recommends two of them: $2,4,5-\mathrm{T}$ and $2,4-\mathrm{D}$.

When applied in frills during spring or fall, 2, 4, 5-T ( 16 pounds of acid equivalent in 100 gallons of diesel oil) kills over 90 percent of the tree tops, with not much sprouting from stumps. 2,4-D (16 pounds of acid equivalent in 100 gallons of diesel oil) is a little cheaper but not quite so thorough. Both treatments cost slightly more than Ammate solution in frills but are more effective, especially in sprout reduction.

Trunk spraying with the oil solution of $2,4,5-\mathrm{T}$ is also useful (fig. 15C). Scrub oaks and hickory were killed by spraying the lower 16 inches of the trunks until the bark was wet. Trunk spraying costs nearly one-third more than pouring solution into frills, but ax work is eliminated and the costs may be reduced by further tests. 


\section{IMPROVING MANAGEMENT OF LIVESTOCK AND FORAGE ON FOREST RANGES}

After the great lumber mills had cut out and moved westward, the production of range livestock became a logical occupation for most residents of the pineywoods. The upland soils were too poor for rowcrop farming, but native forage was abundant and free. This situation still exists on several million acres where the pine stand has not recovered adequately. Cattle, hogs, and sheep are the chief types of stock.

In 1944 to 1946, surveys of the grazing situation of Louisiana forest ranges pin-pointed severe problems that needed detailed study and correction.

First of all, meat production per animal is extremely low-about one-third of that possible under good management. This low production results from a combination of factors: serious deficiencies in native forage during fall and winter that are not compensated for by adequate supplemental feeding; low-grade stock and uncontrolled breeding; inadequate control of diseases, insects, and internal parasites; and the general lack of good management that goes with free, unfenced forest range.

Another major problem is that range livestock grazing often prevents successful pine reproduction and growth. Pine seedlings are destroyed by fires that livestock owners set to eliminate old grass and otherwise improve grazing. Livestock destroy pine reproduction directly by rooting, browsing, and trampling. Hogs, for example, relish longleaf pine seed and root up small pines to eat the fleshy part of the roots. Sheep nip succulent spring bids on small longleaf pines. Cattle trample or browse seedlings on over-grazed areas. Much of this damage is in late winter and early spring, when livestock forage is scarce.

It was concluded from these early surveys that forest range grazing research should be concentrated in three closely related projects: Management of livestock, management of forage, and improvement of forage. 


\section{Management of Livestock on Forest Range}

The studies under this project have two major objectives:

To find practical systems of grazing forest ranges with no significant damage to timber; and

To find a system of range beef cattle management that will greatly increase beef production per cow and per acre.

The nature and extent of grazing damage has been determined and reported sufficiently for landowners and livestock owners to eliminate most of the damage, if they work together. However, studies so far have not developed an acceptable management system to increase beef production.

Hog damage to pine reproduction. - Free-ranging woods hogs destroy longleaf pine plantations that are not fenced or otherwise protected for the first 5 to 10 years. Hogs also prevent the establishment and growth of natural longleaf seedlings. Very few longleaf plantations or natural seedling stands in central and southwest Louisiana have been kept free of hogs long enough to produce good stands of second-growth longleaf.

Many people believe that hogs get a spring tonic from eating pine roots. The truth is that the fleshy root has a very high percent of carbohydrates- -80 percent, about equal to corn--and hogs eat the bark because they are hungry. Nearly all hog damage to pines occurs in late winter and spring. At this season pine and oak mast is gone and other food is scarce, but pine roots are succulent and the ground is soft for rooting.

One adult hog can root up and kill seedlings at the rate of 5 or 6 a minute. He can destroy a whole acre of planted seedling $s$ in a day or two (fig. 16). Hogs sometimes return to an area year after year, until all young pines have been rooted out. Longleaf seedlings are especially vulnerable because they often remain in the grass stage of growth for 4 years or more.

Hogs also root up and peel fleshy lateral roots of longleaf and slash pine saplings. This may not kill the trees, but it leaves them susceptible to wind-throw and disease. 


\section{During 1952 a new kind of}

hog damage was noted and studied in La Salle parish, where the hog population is unusually high. The hogs were found to be rooting a basin around 3 - and 4-year-old slash and loblolly pine seedlings and then girdling the bark. Nearly 500 acres of loblolly pine and over 1,000 acres of slash pine in plantations were 50 to 80 percent destroyed in one season. Where hogs have a choice, however, their order of preference is longleaf first, slash second, and then loblolly.

Deer and rabbit repellents $110 \mathrm{x}$

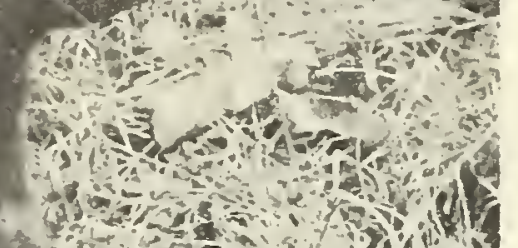

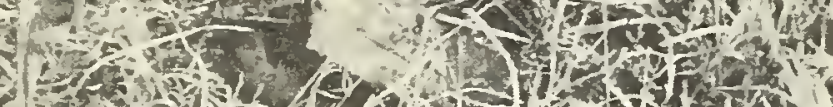
H. $10 \times 1$. Figure 16.--The free-ranging woods hog is probably the worst enemy of longleaf pine.

Damage by cattle. --As a general rule, cattle do not browse pine foliage and have not been reported to cause much damage to pine reproduction. However, with increasing numbers of range cattle and the expanded reforestation program, specific instances of severe cattle grazing damage have been noted during recent years.

Serious damage to pine seedlings has occurred mainly on overgrazed ranges, on spots where cattle concentrated, and in places or seasons in which forage was very sparse. Of course, the most critical damage is on newly planted or seeded areas, where the total number of seedlings is limited. Cattle grazing and trampling may kill small firstyear seedlings and reduce the growth of older ones.

The best solution is to anticipate or recognize and avoid the situations where cattle damage is likely to occur. Here are some general rules to follow: 
1. Do not permit any grazing on direct-seeded areas for at least 3 years after seeding. The amount of grazing allowable thereafter will depend on circumstances too numerous to list here.

2. Protect plantations of $1-0$ pine seedlings from grazing for at least 2 years, if practical. Some seedling loss will occur even under moderate grazing. However, there may be situations where the landowner will feel that the cost of fencing and livestock exclusion will exceed seedling losses from grazing.

3. Do not permit overgrazing of any forest range. For yearlong grazing, each cow needs 12 to 15 acres of open range, 16 to 30 acres of average piney woods range, and 30 to 50 acres in well-stocked timber stands with scattered openings or firebreaks.

4. Watch out for and prevent undue concentrations of cattle. Any treatment that stimulates grass growth usually attracts cattle and results in concentrated grazing. The damage is apt to be great if the treated area is small in comparison to the surrounding range even if it is lightly stocked with cattle.

5. Although this section deals with cattle specifically, it should be kept in mind that pine reproduction may suffer even greater damage from sheep, goats, and horses.

Serious cattle concentration and damage has occurred in these situations:

Burnedareas. Small burns in a large grazing area are bad. Fall or winter burns to prepare planting sites leave essentially nothing to graze until the next spring, except the planted pines.

Cultivated or disked areas. Cattle flock to such areas or strips as soon as the new grass starts growing. In one instance the disturbance of old grass rough by a planting machine was sufficrent to draw cattle from the surrounding open range.

Fertilized areas. Cattle may graze such areas closely enough to destroy the native grasses and pine seedlings. 
Timber-stand-improvement areas. Grass grows vigorously under the dead hardwoods and is choice forage.

Winter feeding of range beef cattle.--During fall and winter the forage on pine forest range is seriously deficient in protein and other nutrients. Since many cattle graze the range yearlong, they need supplemental winter feed if they are to do well.

A feeding study was started in December 1946 in cooperation with the Louisiana Agricultural Experiment Station and the Bankston-Donaldson Stock Farm near Dry Prong, Louisiana. Range beef cattle were divided into three equal lots and fed a daily ration of cottonseed meal during the winter months. One lot received 1.7 pounds of cottonseed meal per head per day, one lot 2.5 pounds, and one lot 3.3 pounds. Feeding continued for three winters. All lots were permitted to graze on forest range during the winter and most of the rest of each year.

Contrary to expectations, the cottonseed meal did not raise beef production appreciably during the three years. Furthermore, no real advantage was gained by feeding 3.3 pounds of meal instead of 1.7 . What the study did reveal was that the range forage in winter has unsuspected deficiencies that cannot be corrected merely by feeding a protein supplement. The extent of these deficiencies was not clear, but the animals seemed to need more carbohydrates, minerals, and vitamins than they were getting. Bull service was poor also, probably because of these same dietary deficiencies.

Management of beef cattle on forest range.-- Why do beef cattle that graze the cutover longleaf pine ranges produce less than half as much beef per cow as those in well-managed western range herds? The low production is expressed in two ways--calf crops of around 50 per.cent, and small calves that weigh from 250 to 325 pounds at weaning time (fig. 17).

In 1951 a study was started on the Longleaf Tract to find a system of herd management and nutrition that will materially increase beef production where range forage makes up a major part of the cattle diet (fig。 18). This is a cooperative study presently using three herds of cattle owned by W. M. Monroe, Alfred Tate and S. C. Duplissey, and $\mathrm{E} . \mathrm{H}$. Winegeart. The cows graze for 8 to 12 months each year on three fenced experimental pastures containing about 580 acres each.

The cattle were placed in the pastures during the fall of 1951 , and preliminary herd management and production records were 


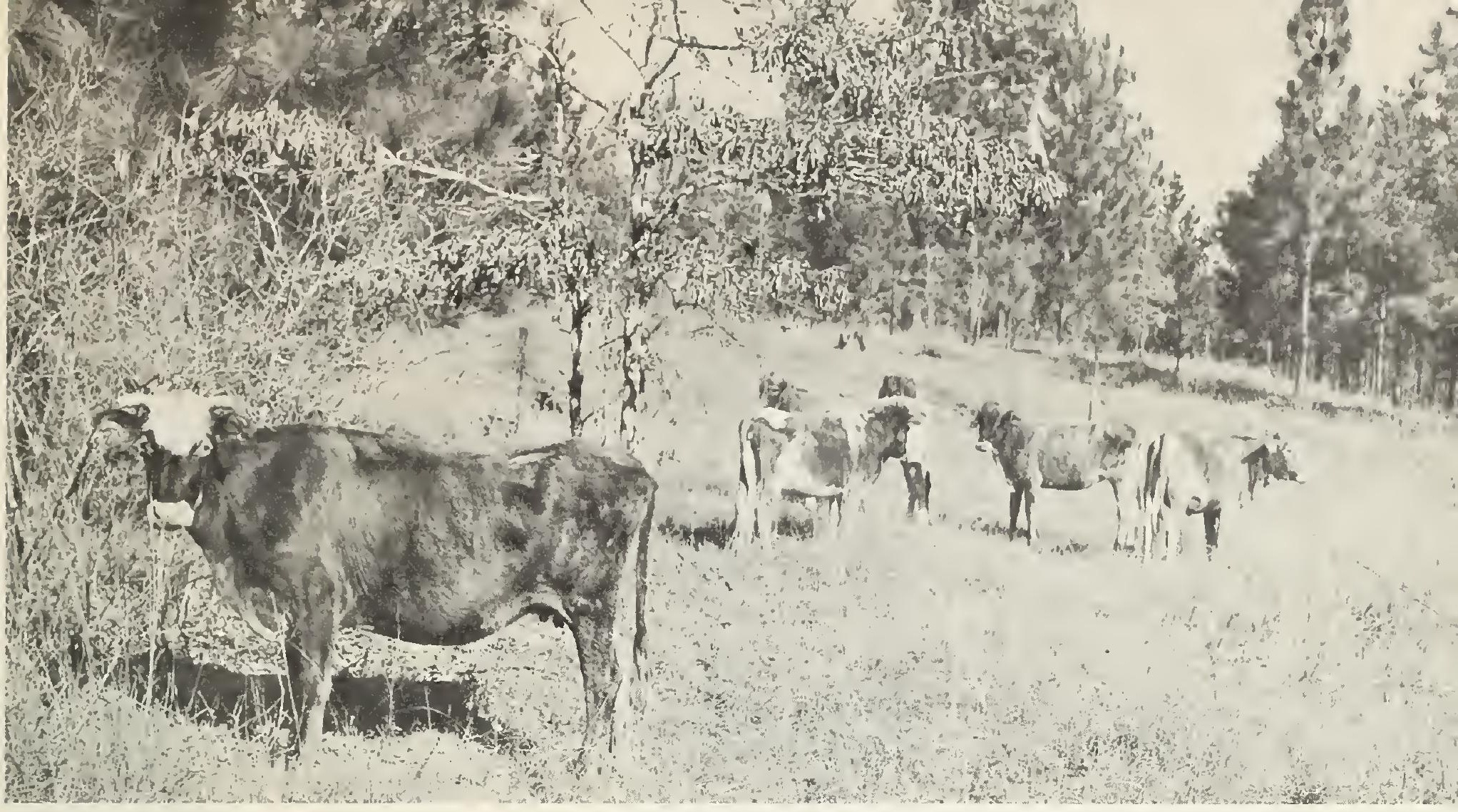

Figure 17. - Cattle that graze unrestricted on pine forest range usually produce one small calf per cow every two years. (Photo by Elemore Morgan)

Figure 18. - This herd is being studied to see if the production of range beef cattle can be materially increased by improved breeding, adequate yearlong nutrition, and the control of diseases, insects, and pests.

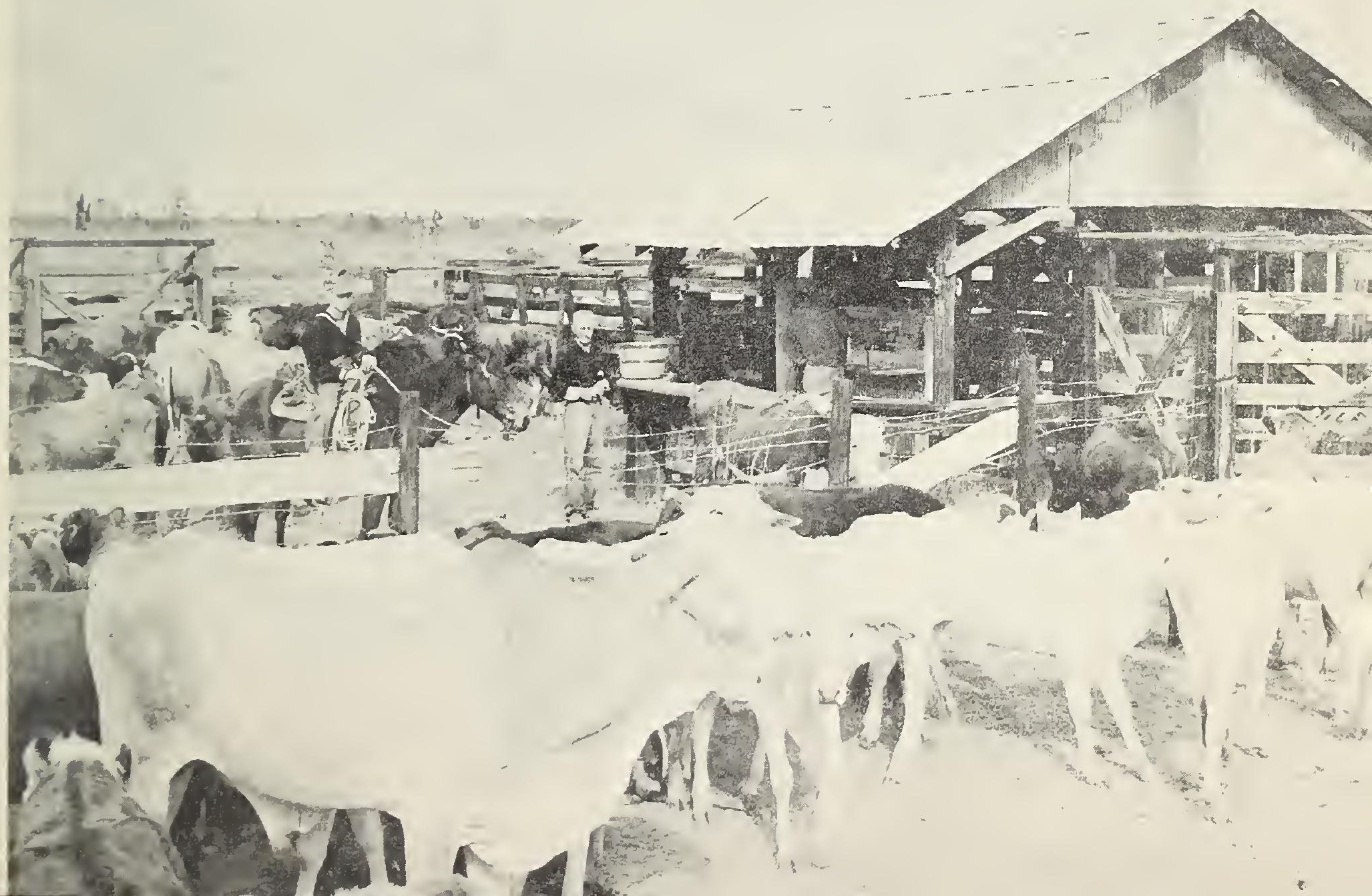


Louisiana forage study.--This project was started in 1944 in cooperation with the Louisiana Agricultural Experiment Station. It was completed in 1949. The work concentrated on determining the forage plants grazed by cattle week by week throughout the year. Samples of the plants were analyzed by the Feeds and Fertilizer Laboratory of Lou is iana State University. In addition, during 1945, 1946, and 1947, a herd of 80 beef cows that grazed most of the year on the forest range was studied to determine grazing habits, weight gains and losses, and beef production.

It was found that grasses make up over 90 percent of the cattle diet on forest ranges, with weeds (forbs) furnishing only four percent and shrubs less than two percent. Bluestem grasses (Andropogon spp.) compose more than half of the ground vegetation. They have better than average palatability and contribute about two-thirds of the cattle diet.

The nutritional analyses of cattle diet samples showed that crude protein was present in adequate amounts for three months only, starting about March 15. There was never quite enough phosphorus in the native forage for best growth of cattle (fig. 20). The cattle weights verified the se analyses: All cattle usually gained weight for about 100 days in spring; calves gained a little but cows lost a little for 100 days during summer and early fall; then from October to March nearly all cattle lost weight heavily if left on forest'range without supplemental feed (fig, 21).

This study yielded additional information about forage production on various kinds of forest ranges in Louisiana and pointed out the need for the other studies reported here. The complete findings are summarized in "Grazing Values for Cattle on Pine Forest Ranges in Louisiana," bulletin 452 of the Louisiana Agricultural Experiment Station.

Forage plant identification.--To aid users of forest range in identifying and evaluating the forage plants, the Alexandria Research Center in 1947 began to collect and study the plants on longleaf pine-bluestem ranges. Several eminent botanists, experts on the various plant families, contributed their services. In 1952, about 80 of the most valuable forage grasses, grassilke plants, forbs, and shrubs were described and illustrated in the "Field Book of Forage Plants on Longleaf Pine-Bluestem Ranges, "published as Occasional Paper 127 of the Southern Forest Experiment Station. The field book 

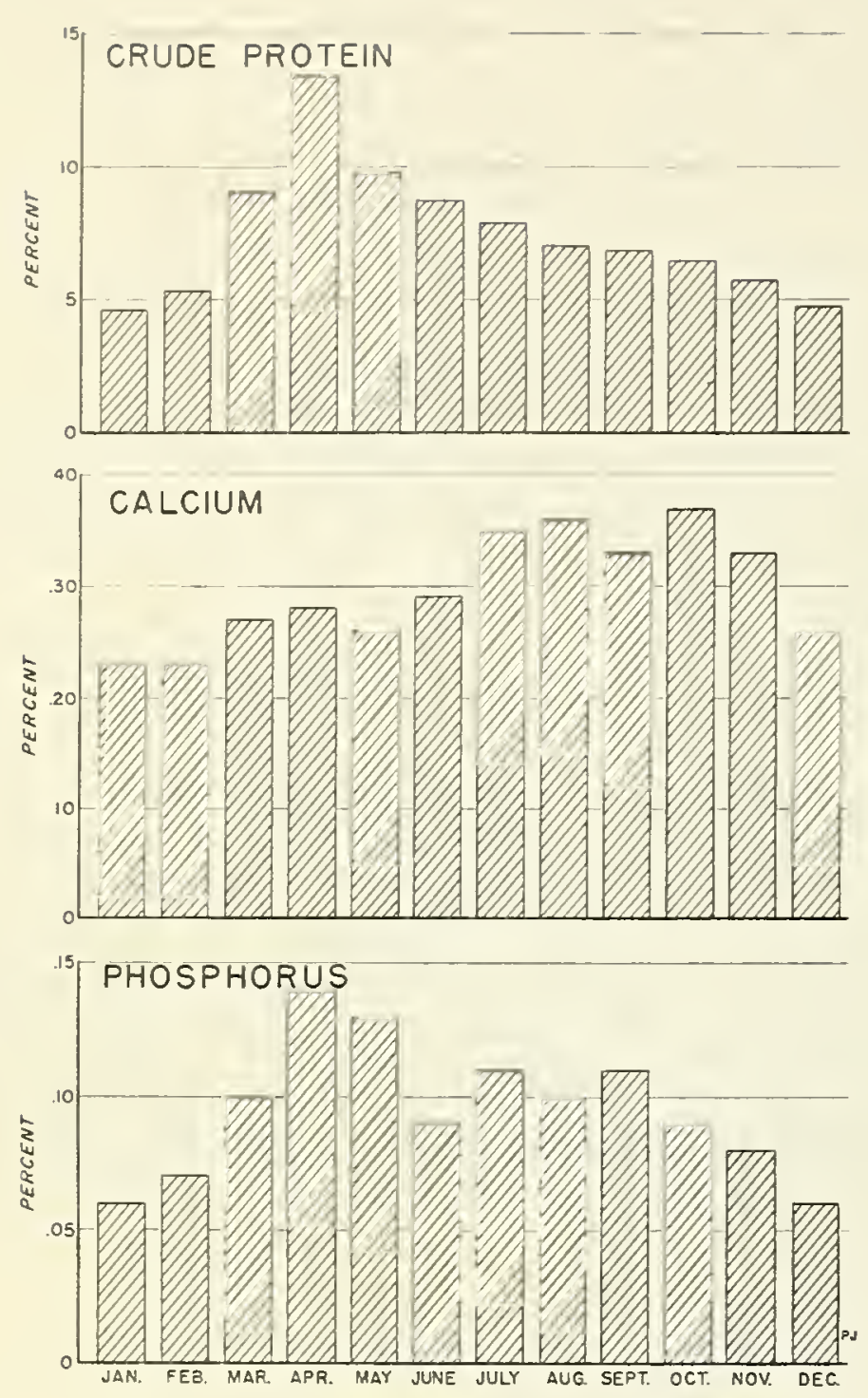

Figure 20.--Crude protein, calcium, and phosphorus in cattle diet on forest range in central Louisiana.
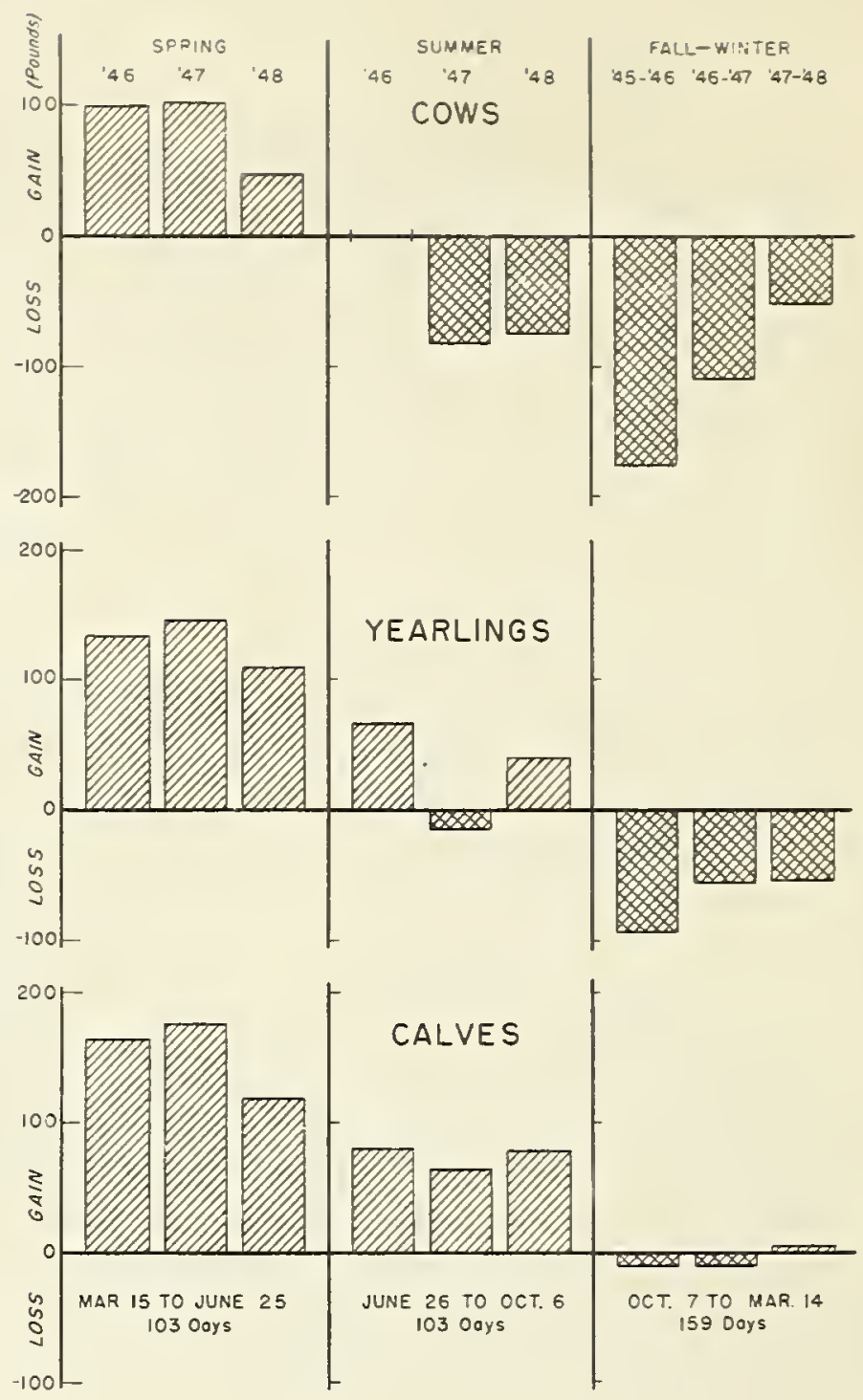

Figure 21.--Seasonal weight gains and losses by beef cattle on forest range in central Louisiana, 194548.

describes the plants so that they can be readily identified, discusses their food value for cattle and game, and lists their special habits, values, or properties.

Herbage production on bluestem range. - - The amount of grass and weed herbage produced on open forest range dominated by pinehill bluestem (Andropogon divergens) was measured at two-week intervals during the growing seasons of 1947, 1948, and 1949. All study plots were protected from grazing but during the 32 weeks from March 15 to October 27 they were harvested with shears at selected frequencies: 2, 4, 7, and 15 times. This was done to get an estimate of the effects 


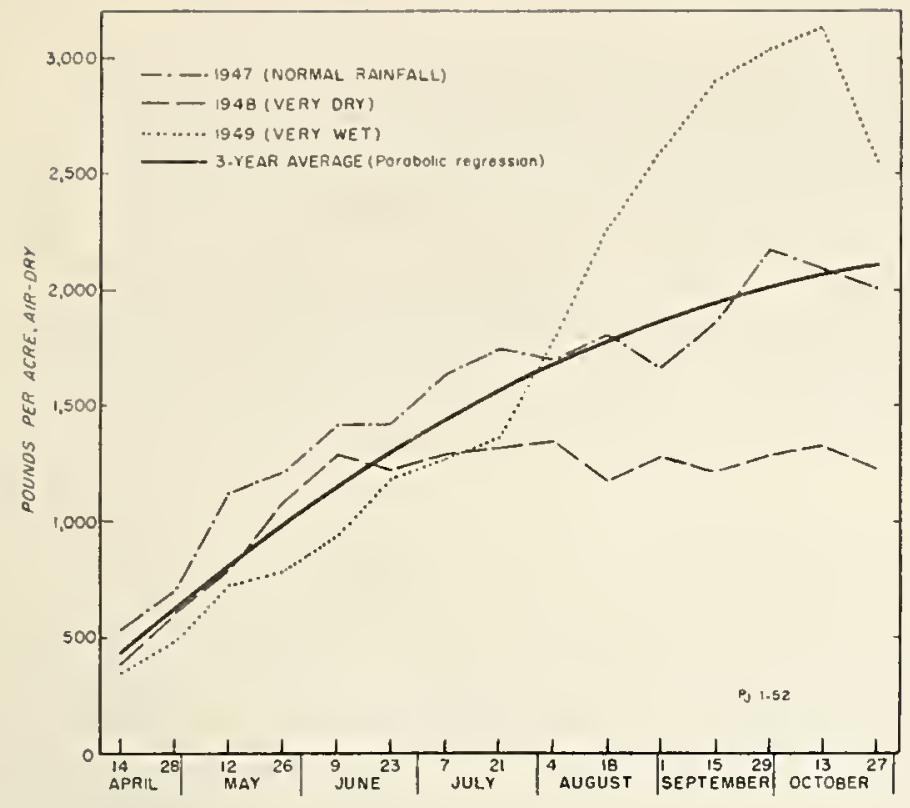

Figure 22.--Cumulative grass production on very open forest range dom inated by bluestem grasses. Central Louisiana, 1947-49. of close and repeated grazing on the production and nutritive value of range forage.

Grass production on an ungrazed range with very few trees was about 2, 121 pounds per acre (air-dry) during 1947, a year of near-normal rainfall. In 1948, when there was a record drouth, production was 1,308 pounds of grass, or 40 percent less than the normal year. The 1949 growing season was comparatively wet, and grass production jumped to 3,083 pounds or 42 percent above the average year.

A "normal" grass production curve, drawn from these data, showed that about half of the grass

was produced by June 1, 75 percent by July 22, and 90 percent by September 5. Further, there was enough winter-spring moisture each year to insure 1,200 to 1,500 pounds of grass by July 1. Growth thereafter varied greatly with the rainfall (fig. 22).

Close and repeated harvesting seriously reduced grass production. Areas harvested 15 times during the season produced only 1,300 pounds of grass per acre in 1947, while areas harvested only at the end of the season yielded 2, 121 pounds (fig. 23). Furthermore, 35 to 50 per cent of the grass stand was killed by this close harvesting in just one season. It was clear that heavy grazing will materially reduce grass production the first year and, if continued, will destroy the valuable bluestem grasses.

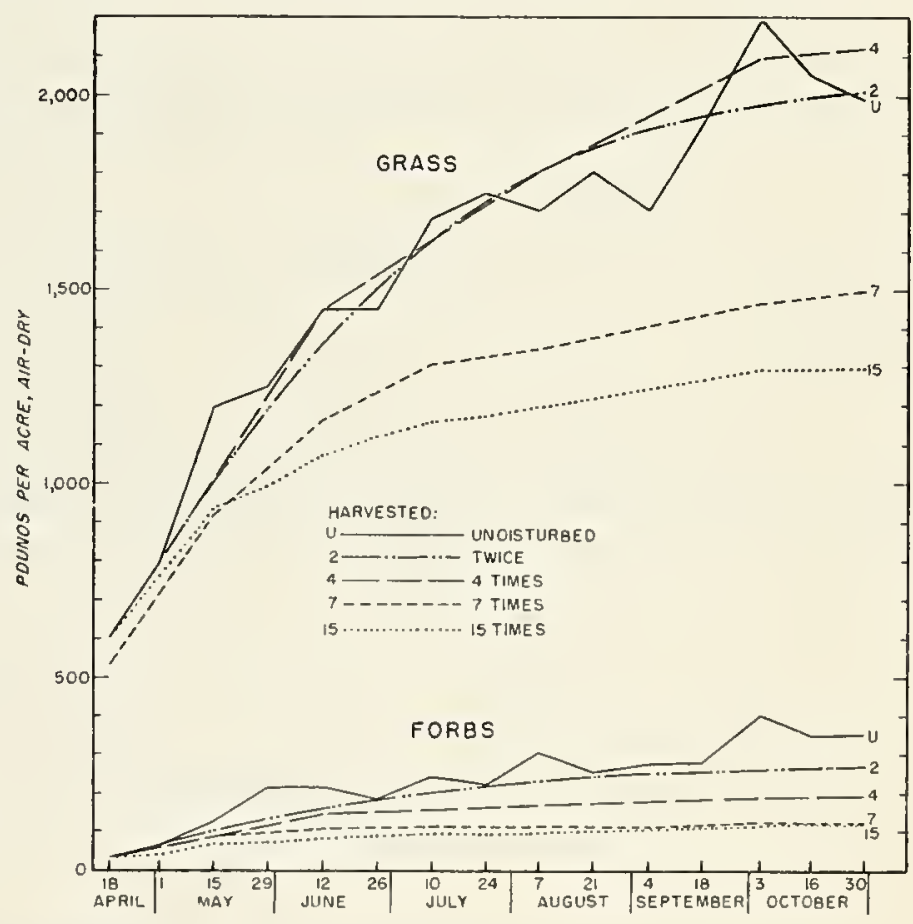

Figure 23.--Cumulative production of herbage under 5 harvesting frequencies. Very openforest range in central Louisiana, 1947. 
Hardwood control increases forage.--Between 1948 and 1950 , grass production doubled on an area that was converted from oaks to pines by underplanting and hardwood control (fig. 19). Prior to 1948 the area supported about 330 scrub oaks per acre. Grass under these hardwoods averaged 700 pounds per acre. In February 1948, pine seedlings were planted at a spacing of 6 by 6 feet, and the hardwoods were girdled or poisoned with Ammate.

Grass growth was stimulated immediately. By 1950, it averaged 1,886 pounds per acre, more than twice as much as before. Since it was also more succulent and nutritious, cattle showed a definite preference for it. By 1958 the increased forage will probably total 6 cowmonths of grazing per acre. With good cattle management, grazing will repay a major part of the cost of hardwood control.

Management of slender bluestem ranges. - A study was started in 1952 to determine how slender bluestem (Andropogon tener) is affected by burning, grazing, and competition from pine trees. The study will also show how three degrees of grazing and burning affect the growth of slash and longleaf pine. The study consists of 18 fenced plots of $1 / 3$ acre each. Six of the plots will be ungrazed, six moderately grazed, and six heavily grazed from April to July of each year. Two plots in each category will be unburned, two will be prescribe-burned, and two will be burned by wildfire. The two burning treatments will be applied early in 1955 and at three-year intervals thereafter. Half of each plot has been planted with pine seedlings--75 longleaf and 75 slash. Records show forage production and utilization, grazing and fire damage to pine trees, changes in the composition of the grass stand, and water infiltration rates.

The main purpose is to find basic facts to guide improved management of forest ranges dominated by slender bluestem. Since the other bluestem species maintain higher nutritive value in summer, fall, and. winter, it is hoped that some of the treatments will reduce the proportion of slender bluestem and increase the more valuable species. Meanwhile, the study is yrelding precise information on forage production, grazing capacity, and grazing damage to pine seedlings.

\section{Improvement of Forage on Forest Range}

One of the major problems in utilizing forest ranges is that the forage has such limited nutritional value in summer, fall, and winter. Many livestock owners want to know if and how they can grow more 
nutritious forage plants on forest ranges, especially for summer-fall grazing. Work has been going on this project since 1945. 2/

The problem is complicated by the fact that most of the land is better sulted to growing timber than to other uses. Cultivation of the forest land and investment in forage improvement must therefore be limited. A happy solution would be to find forage plants that meet these requirements:

Are nutritious in summer and fall or in winter.

Can be established on forest range with little soil disturbance and fertilization.

Will grow successfully in competition with native grasses under moderately intense grazing.

Testing common pasture plants on forest range. --Studies were started in 1945 to find a practical way to establish three common pasture plants on forest land--carpetgrass, Dallisgrass, and common lespedeza.

Applying 200 pounds of calcium metaphosphate and broadcasting 3 pounds of carpetgrass seed per acre on recently burned range in March 1945, followed by close grazing, produced a carpetgrass sod that has stood up under heavy usage for more than 6 years. In fact, cattle kept the sod so closely cropped that the seeded strips have served as firebreaks.

Common lespedeza required about the same treatment as carpetgrass. However, it did grow in a light stand for 3 years when seeded on a range that was fertilized but not burned or cultivated. Dallisgrass could not be established successfully without rather complete cultivation and fertilization. In general, carpetgrass and lespedeza persisted only under close grazing that prevented the growth of native grasses and the establishment of pine seedlings.

Since calcium metaphosphate is not available commercially in this area, it was not used in any other range improvement studies. Basic slag is proving to be as good as calcium metaphosphate.

2/ In January 1954,funds and manpower for the work in range reseeding were transferred to the Agricultural Research Service, U. S. Department of Agriculture. The ARS is continuing this work in close cooperation with the Alexandria Research Center. 
Establishing and grazing firebreaks. - - In 1949, a series of new tests was started to find economical and effective ways to establish sodded strips to serve as firebreaks and provide nutritious summer-fall grazing.

The first test of this series was made in cooperation with the Industrial Lumber Company, Elizabeth, Louisiana, in the Company's slash pine plantations. Here a dense carpetgrass sod was established in one growing season on strips that were disked, fertilized with 1,000 pounds of basic slag per acre, seeded with carpetgrass and common lespedeza in April 1949, and then grazed by cattle season-long (fig. 24). This method was very effective and rapid, but relatively expensive.

In 1950, test plots were installed on the Longleaf Tract to find the minimum treatment needed to establish a sodded firebreak strip. It was concluded that the cheapest method is to prescribe-burn the dry

Figure 24. --This firebreak of carpetgrass sod was established in one season.

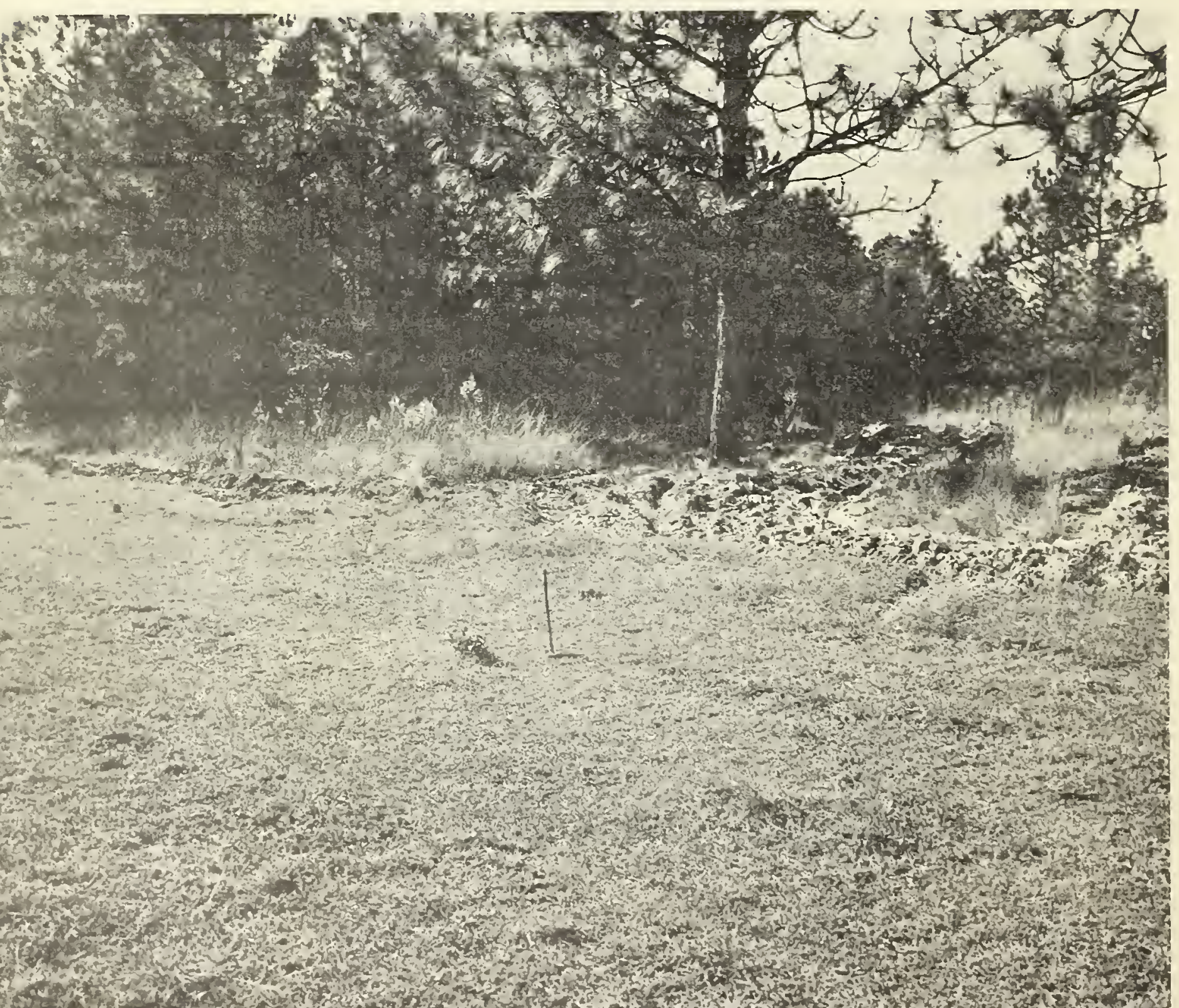


grass during winter and then, in early March, distribute 500 pounds of basic slag per acre and broadcast 3 pounds of carpetgrass seed and 10 pounds of common lespedeza seed per acre. The seeded area must be grazed closely during the first and succeeding growing seasons to control native grasses and favor carpetgrass.

The sod established in the 1950 test has provided about 4.5 cowmonths of grazing per acre each season from 1950 to 1953. In comparison, open forest range bordering the study area has a recommended grazing capacity of 1 cow-month per acre.

Practical tests of grazed firebreaks. --In 1953, four firebreak strips 17 to 20 feet wide and totalling nearly 3 miles in length were established on the Longleaf Tract. Two seedbed preparations were used--disking after the grass was burned, and disking without burning. Fertilizer and seed were distributed at these rates: 1,000 pounds of basic slag, 5 pounds of carpetgrass, and 10 pounds of Kobe lespedeza per acre (common lespedeza was unavailable). Disking without burning was tried because plowing two parallel fire furrows and then burning the grass from between them proved both expensive and hazardous.

Good seedbeds and seedling stands were obtained both with and without burning. Disking in unburned grass was less expensive and is much to be preferred because it avoids the use of fire. The total cost for disking, fertilizing, and seeding was $\$ 26.19$ per acre, or $\$ 52.38$ per mile of firebreak averaging $16-1 / 2$ feet wide.

A good carpetgrass sod was established the first season and provided improved summer-fall grazing for cattle. Data will be taken to see if the strips promote better distribution of grazing. Tests during March 1954 showed the strips to be effective fire barriers. Ground fires did not creep across the strips even on dry windy days. The strips also stopped very hot headfires that were running with a south breeze ( 9 miles per hour).

Forage plant nursery.--Over 30 choice forage plants that are not native to the pinelands but that have grown successfully in other parts of the South are being studied in a nursery established in 1953 on the Longleaf Tract (fig. 25). The plants that do well in the nursery will be tested on cutover pineland to see if they can survive, withstand grazing, and maintain a stand. The successful sod-forming species and low-growing plants that stay green during winter will also be tested on firebreaks. 


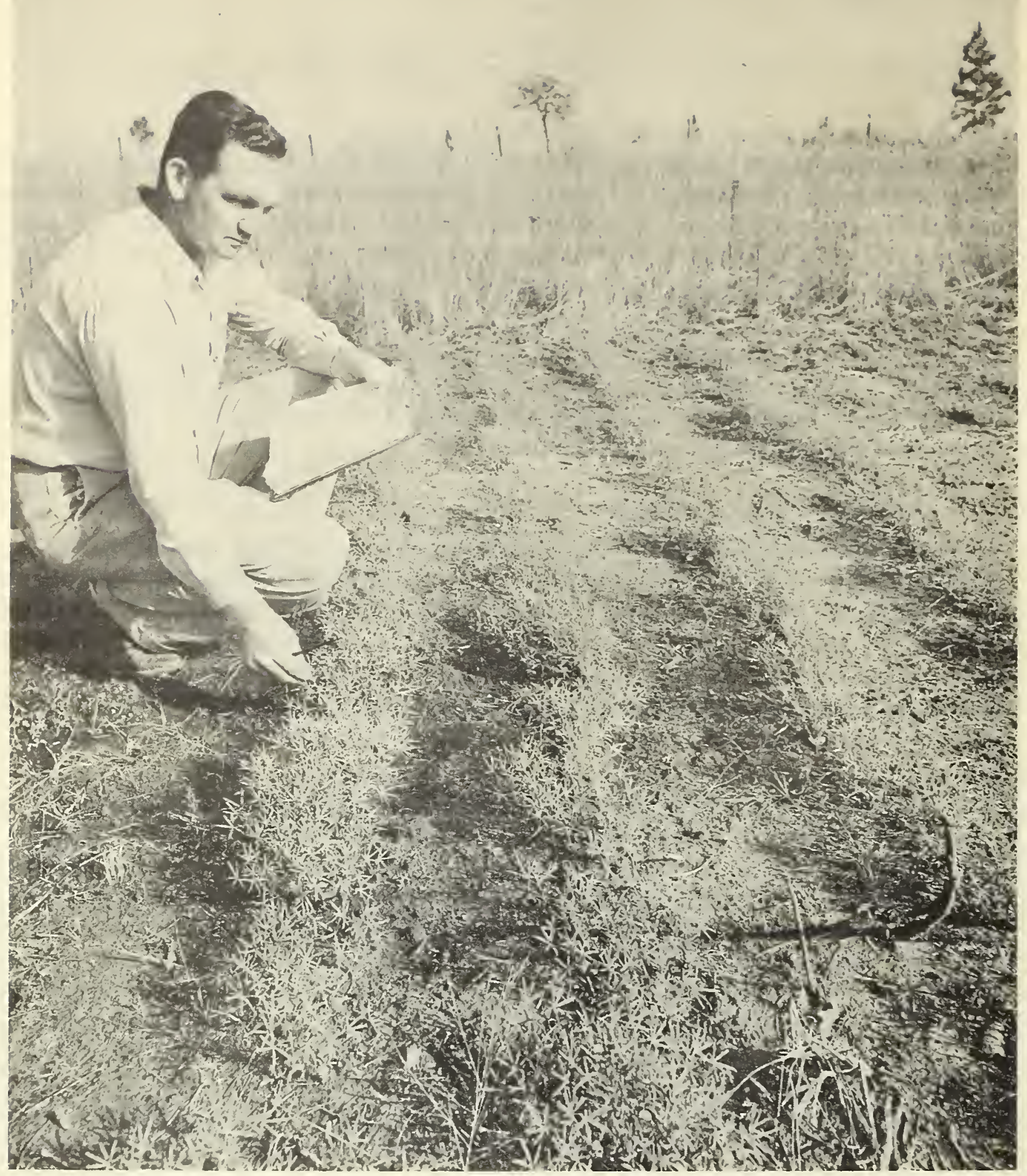

Figure 25. - - In the forage plant nursery a number of species (blue lupine, in this plot) are being tested to see if they can grow successfully on the cutover pinelands. (Photo by Elemore Morgan)

Previous nursery. tests indicated that sericea lespedeza, yellow bluestem, hairy indigo, and subterranean clover will grow on the cutover land, and they are being tested again in the new nursery. 


\section{COST AND RETURNS OF GOOD FOREST MANAGEMENT}

Reliable data on production, costs, and income from improved forest management of cutover land are needed by progressive landowners. Many basic studies are conducted on small experimental plots that do not give satisfactory cost and production data. Therefore, new and improved methods are tested and demonstrated on fairly large areas, either on the Experimental Forest or on private lands in cooperation with landowners.

A study of integrated management of timber and beef cattle has been started on 550 acres of cutover land on the North Pasture of the Johnson Tract. The main objective is to get the tract into high timber production rapidly and economically. Meanwhile, the forage will be utilized by range beef cattle. The most practical methods known or developed by current research will be followed in the reforestation and timber management program. Accurate data will be kept on both the timber and the cattle operation. Early income from sales will be reinvested in the project.

The beef cattle operation began in 19.51 with 20 cattle owned by Mr. John C. Johnston and his son J.W. Johnston. Culling and herd improvement started in 1952, and the her $d$ is to be built up to about 35 head of high-grade cows.

In 1951, the area had a few scattered patches of merchantable timber suitable for sawlogs, crossties, pulpwood, and fence posts. About 250 acres were understocked and needed planting. Hardwood control was necessary on about 200 acres. A salvage cut of damaged and diseased pines was made in 1951 following a severe ice storm. The income was $\$ 2,077$ from 611 cords of pulpwood at $\$ 3.40$ per cord stumpage. Additional income was obtained from 515 tons of longleaf pine stumpwood that sold for $\$ 1.26$ per ton, or $\$ 649$.

In the winter of 1951-52, 60 acres of open land were handplanted with slash pine for $\$ 9.00$ per acre $(800$ seedlings per acre). About 16 acres were hand-planted with longleaf pine 11,200 trees per acre) at a cost of $\$ 13.58$ per acre. About 81 acres were direct-seeded with $3-1 / 2$ pounds of longleaf seed per acre. Direct-seeding costs 
averaged $\$ 4.02$ per acre, including $\$ 3.33$ for seed, $\$ 0.39$ for labor and supervision, and $\$ 0.30$ for controlled burning.

About 95 acres in planted slash and natural longleaf pines were released in 1952 by girdling the overtopping hardwoods for an average cost of $\$ 2.80$ per acre.

So far, the income from timber and stump sales has been $\$ 2,726$, while \$1, 349 has been spent for planting and hardwood control. 


\section{PUBLICATIONS}

A study is not complete until the findings have been published and thus made available to all who may be interested. Following are the titles of the publications that have resulted from the work at Alexandria. Those marked with an asterisk (*) are available for distribution upon request.

\section{Forestry Problems and the Alexandria Research Program}

Cassady, J. T. Forest research at Alexandria. Forest Farmer 6(9): 5, 7. June 1947.

* Cassady, J. T. Researchers study Louisiana's cutover pineland production. Forests and People 1(3): 18-20. October 1951.

\section{$\underline{\text { Planting and Direct Seeding }}$}

* Hopkins, Walt. Machine planting--no cinch: Southern Lumberman 179 (2249): 172-175. December 15, 1949.

Muntz, H. H. Converting scrub oak areas to pine plantations. Journal of Forestry 49: 714-715. October 1951.

Derr, H. J. Direct seeding by air. Forests and People 2(1): 20-21. January 1952 .

Derr, H. J., and Cossitt, F. M. Longleaf pine direct seeding. Journal of Forestry (in press).

Mann, W. F., Jr., and Derr, H. J. Warn landowners to guard against rabbit damage. Forests and People 4(2): 47. April 1954.

* Mann, W. F., Jr. Direct seeding research with longleaf, loblolly, and slash pines. Proceedings, Third Annual Symposium, School of Forestry, Louisiana State University, pp. 9-18. April 1954. 


\section{Plantation Management}

Wakeley, P.C., and Muntz, H. H. Effect of prescribed burning on height growth of longleaf pine. Journal of Forestry 45: 503-508. July 1947.

*Muntz, H. H. Ice damage to pine plantations. Southern Lumberman 175(2201): 142-145. December 15, 1947. Naval Stores Review 57(48): 13,26. February 28, 1948.

Muntz, H. H. Slash pine versus loblolly in central Louisiana. Journal of Forestry 46:766-767. October 1948 .

* Muntz, H. H. Profit from thinning variously spaced loblolly pine plantations. Southern Lumbêrman 177(2225): 125-128. December 15, 1948 。

* Muntz, H. H. Releasing pine planted under scrub oak. Southern Lumberman 181(2273): 200-201. December 15, 1950。

Muntz, H. H. Early release of underplanted pine recommended. Forests and People 1(1):26-28. March 1951.

Mann, W. F.,.Jr。 Rapid growth of loblolly pine. Forests and People 2(1): 14-15, 39. January 1952 .

Mann, W。F。, Jr。 Thirty-six years of thinning research with loblolly pine. Proceedings, First Annual Symposium, School of Forestry, Louisiana State University, pp。1-7。 March 1952.

* Mann, W. F., Jro. Pine best-suited to choice sites in mid-Louisiana: loblolly. Forests and People 3(3): 23, 39. July 1953.

* Derr, H。 Jo, and Mann, W. F。, Jr。 Cost of pruning longleaf pine. Journal of Forestry 51:579-80. August 1953.

Mann, W. F., Jr。 Thinning loblolly pine. Forests and People 4(2): 20-21, 54. April 1954。 


\section{Control of Low-Value Hardwoods}

Peevy, F.A. How to kill blackjack oaks with Ammate. Southern Forest Experiment Station mimeographed paper. 1946. (Revised 1947).

Peevy, F. A. Killing undesirable hardwoods. Southern Lumberman 175(2201): 123-125. December 1947.

Peevy, F. A., and Campbell, R. S. Poisoning undesirable hardwoods. Forest Farmer 6(7): 6-7. April 1947. Naval Stores Review 57(27): 7. October 4, 1947.

Peevy, F. A. Your customer: the forest farmer; here's how chemical tree killers clear timberland. Southern Seedsman 11(3): 16, 56. March 1948.

Cassady, J. T., and Peevy, F. A. From scrubby hardwoods to merchantable pines--timber owners kill defective hardwoods with chemicals. Southern Lumberman 177(2225): 115-119. December $15,1948$.

* Peevy, F. A. How to control southern upland hardwoods with Ammate. U. S.D.A. M-5296, 7 pp. 1949.

Peevy, F. A. How to kill unwanted trees and sprouts with Ammate. Progressive Farmer 64(10): 114, 125. October 1949.

* Peevy, F. A., and Campbell, R. S. Poisoning southern upland weed trees. Journal of Forestry 47:443-447. June 1949.

*Campbell, R. S., and Peevy, F.A. Chemical control of undesirable southern hardwoods. Journal of Range Management 3(2): 118-124. April 1950.

Campbell, R. S., and Peevy, F. A. Poisoning certain undesirable southern hardwoods for forest and range improvement. American Midland Naturalist 44(2): 495-505. September 1950.

Campbell, R. S. Hardwood control. Forest Farmer Manual, second edition, Forest Farmer 10(5): 25-28. February 1951.

*Peevy, F. A., and Grano, C.X. ABC's of hardwood control. Southern Lumberman 185(2321): 211-213. December 15, 1952. 
* Peevy, F.A. Chemical control of southern upland hardwoods. Proceedings, Second Annual Symposium, School of Forestry, Louisiana State University, pp. 35-41. April 1953.

\section{Grazing Damage to Pine Seedlings}

Hopkins, Walt. Pigs in the pines. Forest Farmer 7(1):3, 8. October 1947.

Hopkins, Walt. Piney woods hog hunt. Forest Farmer 7(2): 3, 7. November 1947 .

*Hopkins, Walt. Hogs or logs? Southern Lumberman 175(2201): 151-153. December 15, 1947. Naval Stores Review 57(43): 12-13. January $24,1948$.

Hopkins, Walt. Piney woods porkers turn bark into bacon. Naval Stores Review 57(48): 16-17. February 28, 1948.

Hopkins, Walt。 Louisiana hog hunt. Naval Stores Review 57(52): 16-17. March 27, 1948.

Hopkins, Walt. Hog dog: American Forests 55(12): 20-22. December 1949.

Hopkins, Walt. Hungry cows and planted pines. Progressive Farme $r$ (Ark。-La。-Miss。 edition) 66(12): 109. December 1951.

*Hopkins, Walt, Woods hogs vs, pine logs. Louisiana Forestry Association special publication. 14 pp. 1951.

Peevy, F. A., and Mann, W. F。, Ir。 Slash and loblolly pine plantations destroyed by hogs. Forests and People 2(4): 20, 37. December 1952 . 


\section{Timber and Livestock Production Combined}

Campbell, R. S. Timber and cattle. Forest Echoes 6(9): 6-7, 14. October 1946.

Campbell, R. S., and Cassady, J. T. Bridging the gap: cattle can help the tree farmer. Southern Lumber Journal 51(3): 19-20, 87. 1947.

* Bond, W. E., and Campbell, R. S. Planted pines and cattle grazing-a profitable use of southwest Louisiana's cut-over pine land. Louisiana Forestry Commission Bulletin 4, 28 pp. 1951.

Hopkins, Walt. Grazing in the cut-over longleaf pine region. Journal of Forestry 50: 384-386. May 1952.

Cassady, J. T., and Campbell, R. S. A near dozen essentials go into the making of a good forest grazing lease. Progressive Farmer 67(5): 96. May 1952.

\section{Management of Forest Range Forage}

Campbell, R. S. Forest range grass best during spring. Coastal Cattleman $11(4): 7$. June 1945 .

Campbell, R. S. Determination of grazing values of native vegetation on southern pine forest ranges. Ecology 27: 195-204。 July 1946.

* Cassady, J. T., and Shepherd, W. O. Grazing on forested lands Fin the South]. Grass (Yearbook of Agriculture, 1948) pp. 468-47 $\overline{2}$. Separate No. 2065. U.S. Government Printing Office, Washington, D. C. 1948 .

* Campbell, R. S., and Cassady, J. T. Determining forage weight on southern forest ranges. Journal of Range Management 2(1): 30-32. Janua ry 1949.

* Cassady, J. T. Utilizing forage on longleaf pine forest ranges. Association of Southern Agricultural Workers, Forestry Section Symposium, 10 pp. 1949.

* Campbell, R. S., and Cassady, J. T. Grazing values for cattle on pine forest ranges in Louisiana. Louisiana Agricultural Experiment Station Bulletin 452, 31 pp. May 1951。 
* Campbell, R. S. , and Cassady, J. T. Instructions for forage weight method of range inventory for use on southern national forests. Southern Forest Experiment Station, 12 pp. July 1951.

* Cassady, J. T., and Campbell, R. S. Pine forest ranges in Louisiana. Southern Forest Experiment Station, 7 pp. March 1951.

*Cassady, J. T. Bluestem range in the piney woods of Louisiana and east Texas. Journal of Range Management 4: 173-177. May 1951.

* Langdon, O. G。, Bomhard, Miriam, and Cassady, J. T. Field book of forage plants on longleaf pine-bluestem ranges. Southern Forest Experiment Station Occasional Paper 127, 117 pp. June 1952.

* Cassady, J。 T. Herbage production on bluestem range in central Louisiana. Journal of Range Management 6:38-43. January 1953.

*Campbell, R。S., and Cassady, J. T. Moisture and protein in forage on Louisiana forest ranges. Journal of Range Management 7: $41-42$. January 1954.

\section{Improving Forest Range Forage}

*Campbell, R. S., and Peevy, F. A. Grazing values on southern pine lands reduced by hardwood invasion. Southern Lumberman 171 (2153): 230, 232, 234-235. December 15, 1945.

*Cassady, J. T。 Grass production doubled by control of scrub oak. Journal of Forestry 50:462-463. June 1952。

*Peevy, F. A. Fertilizing and seeding forage on forest range in Louisiana. Agronomy Journal 45: 164-166. April 1953. 
* Cassady, J. T. Feed, forage, and forests: The need for winter feed. Coastal Cattleman 13(8): 7-8. October 1947 .

Hopkins, Walt. Don't wait until Christmas. Progressive Farmer (Miss.-Ark. -La. edition) 65(12): 17. December 1950。

Cassady, J. T. Grazing on forest land. Forest Farmer Manual, seconá edition. Forest Farmer 10(5): 86, 88, 90. February 1951.

Cassady, J. T. Grazing on forest lands in Louisiana. Forests and People 1(2): 16-17, 38-41. July 1951。 


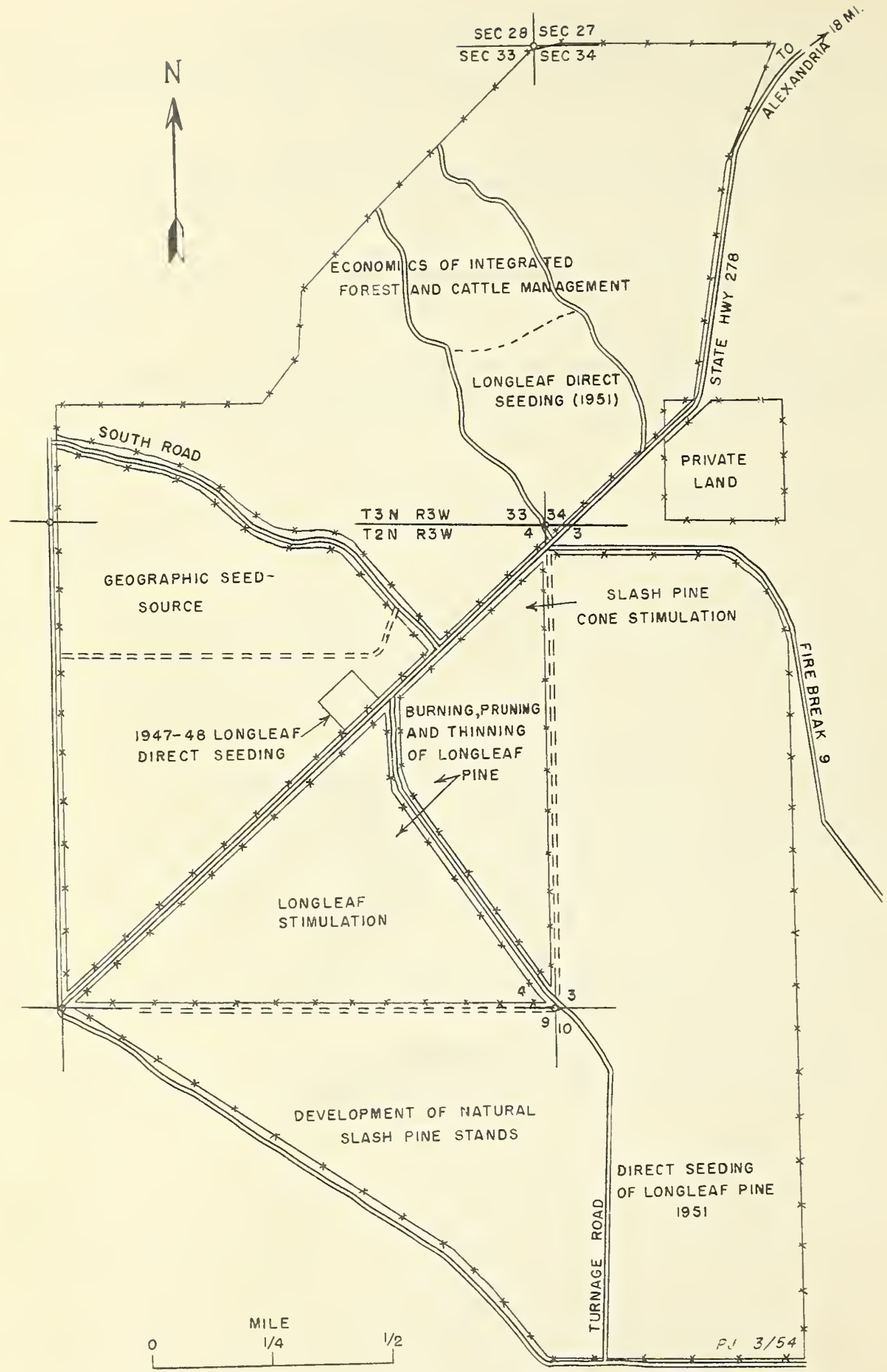

Figure 26.-- J.K. Johnson Tract, Polustris Experimental Forest. 


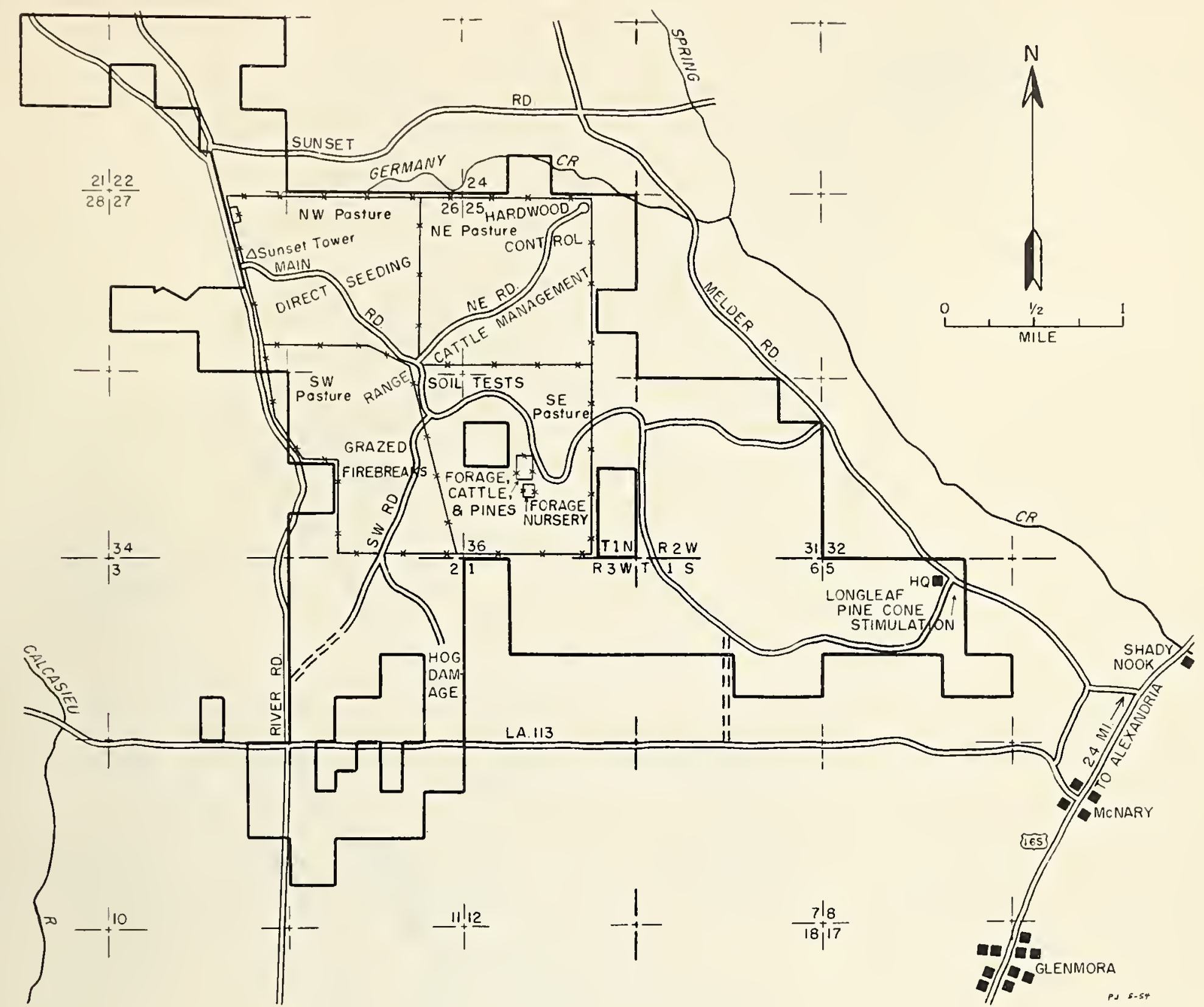

Figure 27.-- Longle of Tract, Palustris Experimental Forest. 


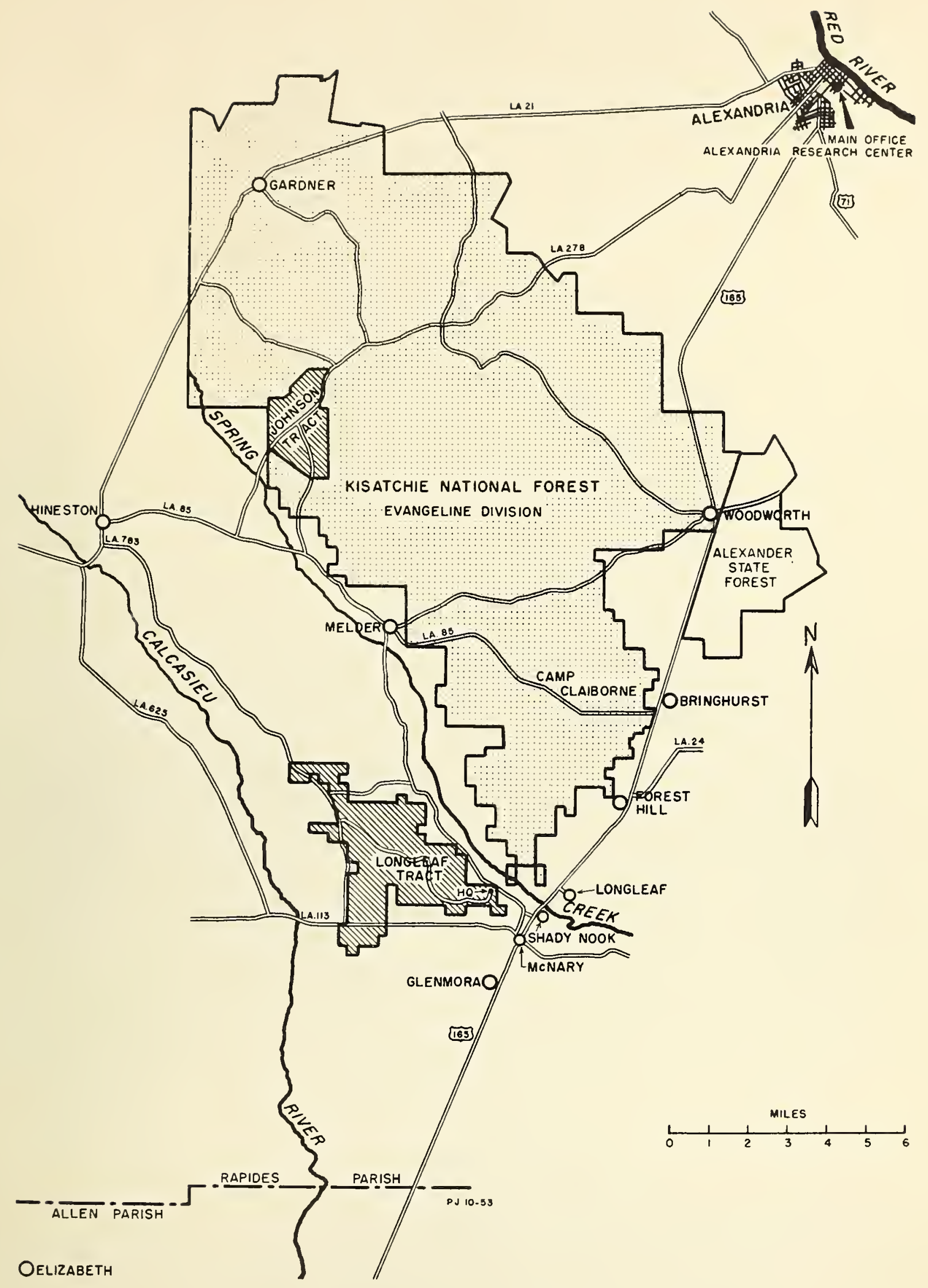

Figure 28.-- Main roads to Johnson Tract and Longleaf Tract, Palustris Experimental Forest. 


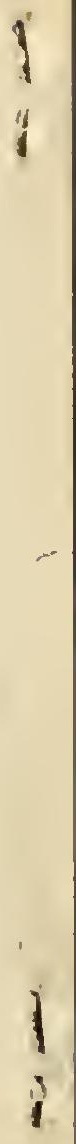

i

1 